\title{
Genetic, environmental and biomarker considerations delineating the regulatory effects of vitamin $D$ on central nervous system function
}

\author{
Andrea Stephenson ${ }^{1,2}$, John C. L. Mamo ${ }^{1,3}$, Ryusuke Takechi ${ }^{1,3}$, Mark J. Hackett ${ }^{1,4}$ and Virginie Lam ${ }^{1,3 *}$ \\ ${ }^{1}$ Curtin Health Innovation Research Institute, Faculty of Health Sciences, Curtin University, Perth, Australia \\ ${ }^{2}$ School of Pharmacy and Biomedical Sciences, Faculty of Health Sciences, Curtin University, Perth, Australia \\ ${ }^{3}$ School of Public Health, Faculty of Health Sciences, Curtin University, Perth, Australia \\ ${ }^{4}$ School of Molecular and Life Sciences, Faculty of Science and Engineering, Curtin University, Perth, Australia \\ (Submitted 1 March 2019 - Final revision received 16 September 2019 - Accepted 16 October 2019)
}

\begin{abstract}
Studies show that vitamin D (vit-D) $(25(\mathrm{OH}) \mathrm{D})$, the bioactive metabolite $\left(1,25(\mathrm{OH})_{2} \mathrm{D}_{3}\right)$ and vit-D receptors (vit-D receptor; protein disulphide isomerase, family A member 3) are expressed throughout the brain, particularly in regions pivotal to learning and memory. This has led to the paradigm that avoiding vit-D deficiency is important to preserve cognitive function. However, presently, it is not clear if the common clinical measure of serum 25(OH)D serves as a robust surrogate marker for central nervous system (CNS) homeostasis or function. Indeed, recent studies report CNS biosynthesis of endogenous $25(\mathrm{OH}) \mathrm{D}$, the CNS expression of the CYP group of enzymes which catalyse conversion to $1,25(\mathrm{OH})_{2} \mathrm{D}_{3}$ and thereafter, deactivation. Moreover, in the periphery, there is significant ethnic/genetic heterogeneity in vit- $\mathrm{D}$ conversion to $1,25(\mathrm{OH})_{2} \mathrm{D}_{3}$ and there is a paucity of studies which have actually investigated vit-D kinetics across the cerebrovasculature. Compared with peripheral organs, the CNS also has differential expression of receptors that trigger cellular response to $1,25(\mathrm{OH})_{2} \mathrm{D}_{3}$ metabolites. To holistically consider the putative association of peripheral (blood) abundance of $25(\mathrm{OH}) \mathrm{D}$ on cognitive function, herein, we have reviewed population and genetic studies, preclinical and clinical intervention studies and moreover have considered potential confounders of vit-D analysis.
\end{abstract}

Key words: Vitamin D: Brain: Cognition: Cerebral vitamin D metabolism: Ageing: Neurodegenerative disorders: Vitamin D measurement

Vitamin D (vit-D) is a lipid-soluble vitamin well-documented for its role in the development and maintenance of skeletal health, as well as maintenance of $\mathrm{Ca}$ and $\mathrm{P}$ homeostasis ${ }^{(1-5)}$. Advances in molecular and cellular biology now show that vit-D has pleiotropic effects and perhaps direct effects within the central nervous system $(\mathrm{CNS})^{(6)}$. Proposed mechanisms include maintaining neuronal $\mathrm{Ca}$ regulation and signalling, regulation of neurotrophic factors, enhanced neurotransmission, synaptogenesis, neurogenesis, neuroprotection and inhibition of degenerative processes, including apoptosis ${ }^{(7-10)}$.

Presently, the recommended serum concentration range for vit-D is primarily based on historical studies in the context of skeletal health; however, it is unknown if this is appropriate when considering CNS integrity and cognitive function ${ }^{(11,12)}$. There is a substantive body of evidence that collectively demonstrates health risks associated with vit-D deficiency, including endocrine, autoimmune, metabolic, bone and cardiovascular disorders ${ }^{(13-23)}$. However, the putative effects of vit-D deficiency and by extension vit-D supplementation on CNS function are contradictory. An emerging body of pre-clinical and clinical studies suggests an inverse U-shaped association with low and greater abundance of serum vit-D both correlated with neurocognitive deficits ${ }^{(14,24,26)}$. Whilst the mechanisms for the latter are presently not established, preclinical studies suggest that chronically heightened levels of serum vit-D may compromise cognitive performance through a cerebrovascular axis. In two rodent species, dietary-induced hypervitaminosis-D increased cerebral capillary permeability, resulting in inappropriate kinetics of plasma proteins from blood into brain parenchyme and neurovascular inflammation ${ }^{(24)}$, whilst genetically engineered mice with hypervitaminosis-D show an accelerated ageing phenotype ${ }^{(26,27)}$. Whilst the physiological sequelae associated with vit-D deficiency are reasonably well established, the putative detrimental effects of exaggerated vit-D are noteworthy in the context of public health

Abbreviations: BBB, blood-brain barrier; CNS, central nervous system; FGF-23, fibroblast-growth-factor-23; HPLC, high-pressure liquid chromatography; PDIA3, protein disulphide isomerase, family A member 3; RCT, randomised controlled trial; VDBP, vit-D binding protein; VDR, vitamin D receptor; vit-D, vitamin D.

* Corresponding author: Dr Virginie Lam, email Virginie. Lam@curtin.edu.au 
trends showing increased self-prescribed use of supplementary vit-D nutraceuticals and clinical trials with interventions of up to $7500 \mu \mathrm{g}$ of vit- $\mathrm{D}_{3}$ per dose $\mathrm{e}^{(28-32)}$.

Collectively, at present, there is no substantiated serum reference range for vit-D that can reliably be indicated to support optimal CNS function ${ }^{(14)}$. Moreover, adding to the complexity of interpreting putative vit-D effects on cognitive performance is that clinically, blood vit-D status is ordinarily indicated by considering the concentration of the inactive metabolite of vit-D, serum 25-hydroxyvitamin-D (25(OH)D), a biomarker of storage rather than biological function per $s e^{(33)}$.

\section{Serum vitamin D synthesis and homeostasis}

Serum abundance of vit-D is partially indicative of the endogenous biosynthesis of cholecalciferol (vit- $\mathrm{D}_{3}$ ) which occurs within the epidermis of mammalian skin ${ }^{(7,34)}$ during exposure to UV-B radiation (290-315 $\mathrm{nm}$ range). However, in addition, serum vit-D is influenced through exogenous sources provided through the ingestion of either plant-derived food commodities enriched in ergocalciferol (vit- $\mathrm{D}_{2}$ ); animal meats and dairy containing both cholecalciferol and ergocalciferol or through nutraceutical supplements (principally provided as cholecalciferol) ${ }^{(34)}$ (Fig. 1).

\section{Peripheral synthesis and metabolism of vitamin D}

Significant hepatic uptake of both skin and dietary-derived vit- $\mathrm{D}_{3}$ and vit- $\mathrm{D}_{2}$ occurs when they are hydroxylated by the microsomal cytochrome P450 25-hydroxylase enzyme, CYP2R1, to 25-hydroxyvit-D (calcidiol (25(OH)D)). In blood, the $25(\mathrm{OH}) \mathrm{D}$ is thereafter chaperoned associated with the vit-D binding protein (VDBP), which can subsequently be internalised by the proximal tubule within the kidney via megalin, a transmembrane receptor protein with high affinity for VDBP (Fig. 1) ${ }^{(35)}$. Principally within the kidney, CYP27B1 converts $25(\mathrm{OH}) \mathrm{D}$ to the biologically active metabolite 1,25-dihydroxyvit-D (calcitriol $\left(1,25(\mathrm{OH})_{2} \mathrm{D}_{3}\right)$ ), where it is released into circulation as an endocrine modulator. In blood, the biologically active $1,25(\mathrm{OH})_{2} \mathrm{D}_{3}$ acts on target cells including cells of the parathyroid glands, osteoblasts, dendritic cells, $\mathrm{T}$ cells and keratinocytes. Ordinarily, homeostasis of the active metabolite is normally strictly controlled by highly regulated co-expression within kidney by CYP27A1, which deactivates $1,25(\mathrm{OH})_{2} \mathrm{D}_{3}$ as a consequence of conversion to 24,25 -dihydroxyvitamin-D $\left(24,25(\mathrm{OH})_{2} \mathrm{D}_{3}\right)^{(36-39)}$.

The catalytic conversion of $25(\mathrm{OH}) \mathrm{D}$ to $1,25(\mathrm{OH})_{2} \mathrm{D}_{3}$ is thought to be principally regulated via ionised $\mathrm{Ca}$ homeostasis $^{(40,41)}$. When blood Ca is low, parathyroid hormone is released, stimulating expression of CYP27B1 and decreasing CYP24A1, resulting in an increase of $1,25(\mathrm{OH})_{2} \mathrm{D}_{3}$ synthesis. Increased levels of $1,25(\mathrm{OH})_{2} \mathrm{D}_{3}$ subsequently inhibit parathyroid hormone, thus avoiding potential risk for hypercalcaemia ${ }^{(35,42)}$. Moreover, a negative feedback loop occurs as a consequence of $1,25(\mathrm{OH})_{2} \mathrm{D}_{3}$ to the vit-D receptor (VDR), with down-regulation of transcription for CYP27B1 $1^{(39)}$ and an increased expression of inactivating enzyme, CYP24A1 ${ }^{(43,44)}$. Similarly, blood phosphate is a potent regulator of CYP-mediated conversion of vit-D metabolites. Dietary phosphates and heightened blood abundance stimulate fibroblast growth factor-23 (FGF-23) secretion ${ }^{(45-47)}$ by osteocytes in the bone matrix of skeletal tissue. The FGF-23 inhibits kidney CYP27B1 and increases CYP24A1 expression, collectively suppressing $1,25(\mathrm{OH})_{2} \mathrm{D}_{3}{ }^{(48)}$. Conversely, circulating low levels of phosphate increases the production of CYP27B1 and thus increases $1,25(\mathrm{OH})_{2} \mathrm{D}_{3}$ concentrations in the blood; the latter would then stimulate FGF-23 production, which would complete the feedback loop and down-regulate CYP27B1 expression $^{(41,48)}$.

In 1987, Stumpf \& O'Brien demonstrated that the bioactive metabolite of vit- $\mathrm{D}, 1,25(\mathrm{OH})_{2} \mathrm{D}_{3}$, could diffuse across the blood-brain barrier (BBB) into brain parenchyme and accumulate in nuclei of the amygdala, hippocampus, hypothalamus, thalamus, pallium, pons, midbrain and cerebellum ${ }^{(49)}$. Stumpf and colleagues observed that the distribution of cerebral $1,25(\mathrm{OH})_{2} \mathrm{D}_{3}$ was non-random and in tight regulation with endocrine, autonomic, sensory and motor systems ${ }^{(49)}$. Indeed, present clinical studies have substantiated that cerebrospinal fluid homeostasis of vit-D is associated with serum abundance of vit-D, supporting current dogma that modulating peripheral metabolism may have CNS modulatory effects ${ }^{(50)}$.

\section{The vitamin $D$ receptor}

The VDR is a member of the nuclear receptor superfamily and acts as a $1,25(\mathrm{OH})_{2} \mathrm{D}_{3}$-inducible transcription factor ${ }^{(51-53)}$. In most cell types including neuronal cells, VDR are predominantly (58\%) found in the nucleus ${ }^{(54)}$; however, observational studies have also shown VDR on the plasma membranes of cells ${ }^{(55)}$ and within the cytosol ${ }^{(54)}$. Genomic effects mediated by VDR consist of the activation and repression of gene transcription. First, the internalisation of $1,25(\mathrm{OH})_{2} \mathrm{D}_{3}$ forms a complex with a retinoid X receptor (either $\operatorname{RXR} \alpha, \operatorname{RXR} \beta$ or $\operatorname{RXR} \gamma$ ) and VDR within the cell ${ }^{(52,56)}$. The $1,25(\mathrm{OH})_{2} \mathrm{D}_{3}$-VDR-RXR complex then binds to specific enhancer elements, referred to as vit-D response elements (VDRE) ${ }^{(52)}$, within the regulatory regions of target genes in the DNA. In a $1,25(\mathrm{OH})_{2} \mathrm{D}_{3}$-dependent manner, the complex recruits various chromatin-active coregulatory complexes, thereby facilitating gene-selective transcription ${ }^{(56-59)}$ (Fig. 1).

\section{Vitamin D receptors and the cytochrome P450 enzymes in brain}

It was not until commercial antibodies became available that research groups such as Veenstra et al. ${ }^{(60)}$ and Prufer et al. ${ }^{(61)}$ were able to map VDR expression throughout the rodent brain. Many studies have demonstrated the presence of VDR in the brain via Western blot, immuno-fluorescent and quantitative RNA techniques ${ }^{(9,55,62-65)}$; however, some researchers disputed these findings and suggested relatively low VDR abundance or exaggerated measures of $\mathrm{VDR}^{(66,67)}$. The uncertainty with respect to CNS VDR abundance is partly based on the work by Wang et al., who did not detect VDR in the rat or human brain using ELISA and immunohistochemical methodologies ${ }^{(68)}$. However, in 2014, Eyles and colleagues provided further 
Central Nervous System

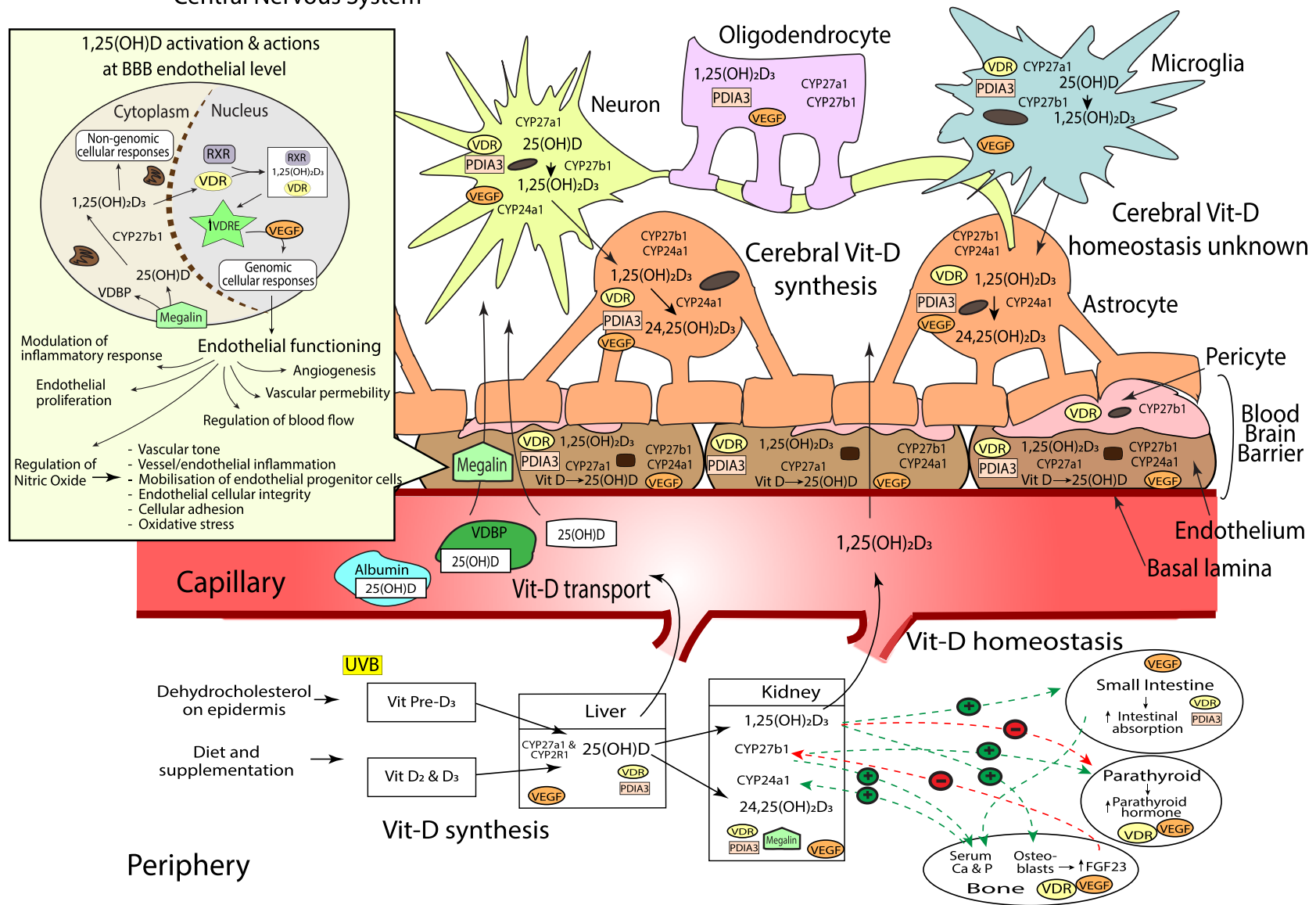

Fig. 1. (Colour online) Sources of vitamin $D(v i t-D)$, peripheral and cerebral synthesis and homeostasis, blood and blood-brain barrier (BBB) transport. Vit-D is obtained by the conversion of dehydocholesterol on the epidermis when exposed to UVB (vit- $D_{3}$ ), diet and supplementation (vit- $D_{2}$ and $\left.D_{3}\right)$. Vit- $D_{2}$ and $D_{3}$ metabolites are converted to 25(OH)D (25-hydroxycholecalciferol) by CYP2R1 and CYP27A1 hydroxylase enzymes in the liver, before conversion to active $1,25(\mathrm{OH})_{2} \mathrm{D}_{3}(\mathrm{calcitriol}$, by CYP27B1, or inactive $24,25(\mathrm{OH}) 2 \mathrm{D}_{3}(24,25-$ Dihydroxycholecalciferol) by CYP24A1 in the kidneys. Hydroxylation enzymes CYP27A1, CYP27B1 and CYP24A1, and vit-D receptors, VDR and PDIA, have been shown in varying concentrations throughout the brain. Neurons, endothelial cells and microglial express CYP27A1, CYP27B1, CYP24A1, VDR and PDIA. Astrocytes express CYP27A1, CYP24A1, VDR and PDIA. Oligodendrocytes express CYP27A1 and PDIA3; and pericytes express CYP27B1 and VDR. Vit-D synthesis from vit-D to $25(\mathrm{OH}) \mathrm{D}$ takes place within endothelial cells and neurons, before further hydroxylation to $1,25(\mathrm{OH})_{2} \mathrm{D}_{3}$ in the neurons and microglia. $1,25(\mathrm{OH})_{2} \mathrm{D}_{3}$ activates either genomic actions via VDR or non-genomic actions via PDIA3. As VDR is expressed in lower quantities in brain compared with kidney, PDIA3 may act as the main cerebral vit-D receptor. Peripheral vit-D homeostasis is tightly regulated by hormones such as calcium, parathyroid hormone $(\mathrm{PTH})$, fibroblast growth factors (FGF-23) and abundance of $1,25(\mathrm{OH})_{2} \mathrm{D}_{3}$; however, cerebral vitamin $\mathrm{D}$ homeostasis, along with the relationship between peripheral and cerebral homeostasis, remains unknown. Vit-D is predominantly transported in peripheral blood bound to VDBP, but can also be bound to albumin, or free $(<1 \%)$. Albumin can traverse the endothelium via transcytotic mechanisms, whilst free $25(\mathrm{OH}) \mathrm{D}$ and active $1,25(\mathrm{OH})_{2} \mathrm{D}_{3}$ enter the endothelial cell and move across the BBB into the central nervous system (CNS) via passive diffusion. The BBB consists of the basal lamina, endothelial cells, pericytes and astrocytes. $25(\mathrm{OH}) \mathrm{D}$ bound to VDBP is dependent on internalisation by megalin transport protein. Once internalised, 25(OH)D unbinds from VDBP before conversion to $1,25(\mathrm{OH})_{2} \mathrm{D}_{3}$ within the cytoplasm. $1,25(\mathrm{OH})_{2} \mathrm{D}_{3}$ then translocates into the nucleus where it binds to VDR and retinoid $X$ receptor $(R X R)$. The $1,25(\mathrm{OH})_{2} \mathrm{D}_{3}, \mathrm{VDR}$, RXR complex then binds to target genes that contain a vitamin $D$ response element (VDRE) ${ }^{(62,70,73,75,130)}$. Activation of VDRE promotes expression of vascular endothelial growth factor (VEGF) ${ }^{(234)}$ which is located throughout the brain including astrocytes ${ }^{(235)}$, neurons ${ }^{(236)}$, oligodendrocytes ${ }^{(237)}$, microglial cells ${ }^{(238)}$ and the endothelium at the $\mathrm{BBB}^{(239)}$. VEGF binds to VEGF-specific receptors like those in the endothelium, controlling a wide range of endothelial cellular activities ${ }^{(234)}$. This includes regulation of vascular permeability, endothelial proliferation, activation of angiogenesis, regulation of blood flow via vasodilation/vasoconstriction and modulation of inflammatory response including platelet activation, migration and cell survival ${ }^{(234,240)}$. VEGF also induces the release of nitric oxide (NO) from endothelial cells $^{(241)}$. NO is an important biomolecule which mediates various metabolic pathways ${ }^{(242)}$ including vessel inflammation and integrity, regulation of vascular tone, cellular adhesion and oxidative stress. Additionally, $\mathrm{NO}$ is partly responsible for the mobilisation of endothelial progenitor cells essential for vessel maintenance and repair ${ }^{(243)}$. Vit-D and VEGF dysregulation can therefore substantially modulate endothelial cell function ${ }^{(234)}$.

evidence of cerebral abundance of VDR using proteomic techniques $^{(62)}$.

Recently, another CNS-rich protein has been implicated in rapid intracellular signalling induced by $1,25(\mathrm{OH})_{2} \mathrm{D}_{3}$, namely, protein disulphide isomerase, family A member 3 (PDIA3), a membrane-bound VDR ${ }^{(69)}$. Notably, the PDIA3 expression in brain is orders of magnitude greater than hepatic and renal PDIA3 expression, particularly in the cerebral cortex and hippocampus, regional areas critical to cognitive function (Fig. 1) ${ }^{(69)}$. Consistent with an autocrine pathway, Eyles et $a{ }^{(70)}$ also described the coexpression of CYP27B1 with VDR in human cerebral cortex, hippocampal formation and hypothalamus ${ }^{(9)}$. CYP27B1 and VDR were immunodetected in both neuronal and glial cells, with the expression of CYP27B1 restricted to the cytoplasm, and VDR within the nucleus, respectively (Fig. 1). VDR immunoreactivity was indicated within 
hippocampal formation regions, CA1 and CA2, with less prominence in CA3. Consistent with the regional distribution of VDR, CYP27B1 was clearly indicated throughout the entirety of the CA1, CA2 and CA3-hippocampal formation regions, brain regions pivotal for spatial learning and memory formation and considered one of the most vulnerable regions in Alzheimer's disease pathology ${ }^{(62,70-72)}$ (Fig. 1). The substantive findings by Eyles et al. demonstrating a de novo CNS pathway for $1,25(\mathrm{OH})_{2} \mathrm{D}_{3}$ biosynthesis and cellular activation in brain raises uncertainty as to the relative physiological significance of peripheral (serum) $1,25(\mathrm{OH})_{2} \mathrm{D}_{3}$ homeostasis in the context of CNS function.

\section{Cellular distribution of vitamin D receptor and associated enzymes in the central nervous system}

At a cellular level, Smolders et al. ${ }^{(73)}$ reported immunostaining for VDR in microglia and astrocytes; however, the CYP24A1 enzyme was restricted primarily to astrocytes (Fig. 1). In alignment with these findings, El-Atifi et al. ${ }^{(74)}$ demonstrated CYP2R1 and VDR expression in human pericytes. As major structural and functional cells comprise the neurovascular unit, the aforementioned evidence supports the autocrine/paracrine modes of action of vit-D on neurovascular function (Fig. 1).

Within the neurovascular unit, CYP27A1, CYP27B1 and CYP24A1 expressions have been confirmed in astrocytes, endothelial cells, microglia, oligodendrocytes and notably, with significant expression of CYP27B1 particularly indicated in neurons ${ }^{(75)}$. However, differential expression of the VDR binding proteins has been described. The VDR is expressed principally in astrocytes, whereas PDIA3 mRNA is ubiquitously indicated. For the latter, there was striking abundance found in endothelial cells consistent with a functional role of peripheral (blood) $1,25(\mathrm{OH}) \mathrm{D}$ on vascular function ${ }^{(75)}$. Figure 1 summarises all present evidence for vit-D associated metabolites and receptors that have been characterised in the brain.

\section{Cerebral vitamin $D$ homeostasis relative to peripheral}

vitamin $D$ homeostasis. Vit-D metabolites are able to traverse the $\mathrm{BBB}$ from blood into the brain paranchyme through mechanism which have not been equivocally delineated ${ }^{(76)}$. Unfortunately, there is a paucity of literature considering putative associations between serum and cerebral vit-D homeostasis. Xue et $a l{ }^{(76)}$ showed that rats fed a vit- $\mathrm{D}_{3}$-deficient diet had markedly lower cerebral $25(\mathrm{OH}) \mathrm{D}_{3}$ metabolite concentration in comparison with rats maintained on a vit- $\mathrm{D}_{3}$ supplemented diet. Consistent with the possibility of diffusion or facilitated transport process across the BBB, Xue and colleagues showed that the serum vit- $\mathrm{D}_{3}$ metabolite concentrations correlated with brain vit- $\mathrm{D}_{3}$ metabolite levels. However, the relative significance of peripheral vit-D homeostasis in association with CNS vit-D homeostasis remains largely unexplored.

\section{Vitamin D and cognitive performance}

There is public popularity with the notion that higher vit-D status, indicated by increased serum vit-D $(25(\mathrm{OH}) \mathrm{D}$ as the universal marker of vit-D status), is associated with better cognitive performance and reduced risk of neurodegenerative disorders. The public perception has resulted in the promotion of selfprescribed vit-D supplementation without clinical indication ${ }^{(77)}$.

A number of randomised controlled trials (RCT) and meta-analyses suggest a positive association of serum vit-D with cognition $^{(78)}$, at a threshold serum concentration of $25(\mathrm{OH}) \mathrm{D}$ level $>25 \mathrm{nmol} / \mathrm{l}$. Benefits are indicated on global cognitive performance $^{(79)}$ and in specific cognitive domains including visuospatial skills, language, working memory, memory recall, concentration and attention ${ }^{(80)}$. However, other studies indicate that exaggerated levels of vit-D are also associated with poorer cognitive function ${ }^{(25,81-83)}$. Moreover, adding to the complexity of interpretating vit-D-associated CNS effects is the significant potential confounder of reverse causation and in lack of standardisation and heterogeneity of blood vit-D analytics ${ }^{(82,84)}$.

\section{Hypovitaminosis D and cognitive performance}

Numerous studies report associations between vit-D deficiency and an increased risk of cognitive decline in older adults $^{(14,19,20,85)}$; however, paradoxical findings suggest no such association $^{(81)}$ (See summary of studies to date in Table 1). An international task force considering vit-D and cognition in elderly individuals concluded that hypovitaminosis-D increases the risk of cognitive decline and dementia(14). In Alzheimer's disease, hypovitaminosis-D is associated with a $2 \cdot 4$-fold increased risk for cognitive impairment ${ }^{(14)}$. In the large community-based Framingham Heart Study, there was an association between lower vit-D status and reduced hippocampal volume, poorer measures of neuropsychological function and a greater risk of dementia ${ }^{(86)}$. In agreement with these large cohort studies, Hooshmand et al. ${ }^{(87)}$ reported positive associations between vit-D (25(OH)D) status with cognitive function and a reduction in CSF amyloid- $\beta$ and brain volume. Moreover, regional cerebral blood flow and brain function were found to be positively associated with serum vit-D concentration in Alzheimer's disease patients. A lower concentration of serum vit-D was found to correlate with poorer executive functioning (heterogeneous set of complex processes that controls and regulates other abilities and behaviour); however, episodic memory was generally found to be unaffected ${ }^{(87)}$. Furthermore, Chaves et $a l .{ }^{(88)}$ recently concluded vit-D insufficiency as an independent risk factor for Alzheimer's disease.

In contrast to studies which indicate a positive association between serum vit-D and cognitive performance, an increasing number of prospective cohort studies, including in early childhood to individuals of advanced age, have failed to show a correlation between serum vit-D status and cognitive outcomes. Schneider et al. ${ }^{(89,90)}$ found no association between vit-D deficiency with lower cognitive test scores in a 20 year (median) longitudinal study in late to middle aged adults. Graf et al. ${ }^{(91)}$ reported no association between vit-D and increased risk for mild cognitive impairment, nor did serum vit-D predict the conversion from cognitively normal or mild cognitive impairment to dementia. Other studies have not found any association between low 25(OH)D and cognitive performance ${ }^{(92,93)}$. Using a Mendelian randomisation study design in a recent study, Maddock et al. ${ }^{(94)}$ explored the relationship between serum $25(\mathrm{OH}) \mathrm{D}$ concentration and cognitive function. Data collected 


\section{N British Journal of Nutrition}

Table 1. Summary of randomised controlled trials and observational studies exploring vitamin $D$ (vit-D) and cognitive outcomes

\begin{tabular}{|c|c|c|c|c|c|c|}
\hline $\begin{array}{l}\text { Reference/author/ } \\
\text { year }\end{array}$ & Study design & Sample size/participants & Primary cognitive measures & $\begin{array}{l}\text { Intervention/follow-up } \\
\text { time (if applicable) }\end{array}$ & $\begin{array}{l}\text { Method of vit-D } \\
\text { status measurement }\end{array}$ & Outcome \\
\hline \multicolumn{7}{|c|}{ Randomised controlled trials } \\
\hline $\begin{array}{l}\text { Rossom et al. } \\
\qquad(2012)^{(92)}\end{array}$ & $\mathrm{RCT}$ & $\begin{array}{l}4143 \text { elderly women } \\
\text { (>65 years of age) without } \\
\text { probable dementia }\end{array}$ & $\begin{array}{l}\text { Global cognitive function; } \\
\text { attention; working memory; } \\
\text { verbal knowledge; memory, } \\
\text { spatial ability }\end{array}$ & $\begin{array}{l}10 \mu \mathrm{g} \text { vit- } \mathrm{D}_{3} \\
\text { combined with } \\
\text { calcium carbonate/ } \\
\mathrm{d} \text {; mean follow-up } \\
\text { of } 7.8 \text { years }\end{array}$ & $\begin{array}{l}\text { Serum } 25(\mathrm{OH}) \mathrm{D} \text { not } \\
\text { measured }\end{array}$ & $\begin{array}{l}\text { No associations were reported between vit-D } \\
\text { supplementation and cognitive outcomes }\end{array}$ \\
\hline $\begin{array}{l}\text { Dean et al. } \\
\quad(2011)^{(93)}\end{array}$ & $\mathrm{RCT}$ & $\begin{array}{l}128 \text { healthy young adults } \\
\text { (mean age of } 21.45 \text { years) }\end{array}$ & $\begin{array}{l}\text { Working, response inhibition; } \\
\text { cognitive flexibility }\end{array}$ & $\begin{array}{l}125 \mu \mathrm{g} \text { of vit- } D_{3} / \mathrm{d} \text { for } \\
6 \text { weeks }\end{array}$ & $\begin{array}{l}\text { 25(OH)D (dried } \\
\text { whole blood spot } \\
\text { samples) via } \\
\text { tandem mass } \\
\text { spectroscopy }\end{array}$ & $\begin{array}{l}\text { Vit-D supplementation did not influence cognitive } \\
\text { or emotional functioning }\end{array}$ \\
\hline $\begin{array}{l}\text { Stein et al. } \\
\qquad(2011)^{(97)}\end{array}$ & $\mathrm{RCT}$ & $\begin{array}{l}\text { Sixty-three community } \\
\text { dwelling participants aged } \\
\geq 60 \text { years with mild- } \\
\text { moderate } A D\end{array}$ & $\begin{array}{l}\text { Visuospatial; language; } \\
\text { concentration; attention; } \\
\text { working memory; executive } \\
\text { function and orientation }\end{array}$ & $\begin{array}{l}25 \mu \mathrm{g} \text { and } 150 \mu \mathrm{g} \text { of } \\
\text { vit- } \mathrm{D}_{2} / \mathrm{d} \text { for } \\
8 \text { weeks }\end{array}$ & $\begin{array}{l}\text { Serum } 25(\mathrm{OH}) \mathrm{D} \\
\quad \text { via } \mathrm{RIA}\end{array}$ & $\begin{array}{l}\text { High-dose vit-D supplementation conferred no } \\
\text { benefit for cognition in individuals with } \\
\text { mild-moderate } A D\end{array}$ \\
\hline $\begin{array}{l}\text { Castle et al. } \\
(2019)^{(83)}\end{array}$ & $\mathrm{RCT}$ & $\begin{array}{l}\text { Healthy, postmenopausal } \\
\text { women }(50-70 \text { years of age; } \\
\left.\text { BMI } 25-40 \mathrm{~kg} / \mathrm{m}^{2}\right)\end{array}$ & $\begin{array}{l}\text { Executive functioning; attention } \\
\text { and flexibility of attention; } \\
\text { reaction time working memory } \\
\text { capacity and spatial planning; } \\
\text { motor control }\end{array}$ & $\begin{array}{l}15,50 \text { or } 100 \mu \mathrm{g} \text { vit- } \\
D_{3} / \mathrm{d} \text { for } 12 \text { months }\end{array}$ & $\begin{array}{l}\text { Serum } 25(\mathrm{OH}) \mathrm{D} \\
\quad \text { via } \mathrm{RIA}\end{array}$ & $\begin{array}{l}\text { Differential dosage effects of vit-D3 on specific } \\
\text { cognitive domains were reported. Participants } \\
\text { from the } 50 \mu \mathrm{g} / \mathrm{d} \text { group performed better in } \\
\text { learning and memory measures in comparison } \\
\text { with those taking } 15 \text { and } 100 \mu \mathrm{g} \text { vit-D3/d. } \\
\text { Slower reaction time was observed in } \\
\text { participants on daily } 100 \mu \mathrm{g} \text { vit-D3 }\end{array}$ \\
\hline \multicolumn{7}{|c|}{ Observational studies } \\
\hline $\begin{array}{l}\text { Lam et al. } \\
\quad(2015)^{(100)}\end{array}$ & Cross-sectional & $\begin{array}{l}179 \text { healthy, older aged } \\
\text { individuals ( } 47-84 \text { years } \\
\text { of age) }\end{array}$ & $\begin{array}{l}\text { Verbal episodic memory and } \\
\text { attention }\end{array}$ & $\mathrm{N} / \mathrm{A}$ & $\begin{array}{l}\text { Serum } 25(\mathrm{OH}) \mathrm{D} \\
\text { enzyme } \\
\text { immunoassay }\end{array}$ & $\begin{array}{l}\text { Higher vit-D status was associated with poorer } \\
\text { performance on verbal episodic memory in } \\
\text { middle-aged and older individuals with normal } \\
\text { vit-D-Ca-PTH homeostasis }\end{array}$ \\
\hline $\begin{array}{l}\text { Granic et al. } \\
\quad(2015)^{(25)}\end{array}$ & Cross-sectional & $\begin{array}{l}775 \text { older participants over } \\
85 \text { years }\end{array}$ & Global functioning and attention & N/A & $\begin{array}{l}\text { Serum } 25(\mathrm{OH}) \mathrm{D} \\
\quad \text { via RIA }\end{array}$ & $\begin{array}{l}\text { Low and high season-specific } 25(\mathrm{OH}) \mathrm{D} \text { quartiles } \\
\text { were associated with cognitive deterioration } \\
\text { and poorer overall performance in attention- } \\
\text { specific tasks. Participants in the highest } \\
\text { quartile with increased risk of worsened global } \\
\text { cognition and attention were users of vit-D } \\
\text { supplementation; this was not observed in non- } \\
\text { users of vit-D supplements }\end{array}$ \\
\hline $\begin{array}{l}\text { McGrath et al. } \\
(2007)^{(81)}\end{array}$ & Cross-sectional & $\begin{array}{l}\text { Adolescent group ( } n 1676 \text {, } \\
\text { 12-17 years), adult group } \\
\text { ( } n 4747,20-60 \text { years), } \\
\text { elderly group ( } n 4809 \\
60-90 \text { years) }\end{array}$ & $\begin{array}{l}\text { Verbal and visuospatial learning } \\
\text { and memory; visual attention; } \\
\text { coding speed; concentration; } \\
\text { psychomotor speed }\end{array}$ & $\mathrm{N} / \mathrm{A}$ & $\begin{array}{l}\text { Serum } 25(\mathrm{OH}) \mathrm{D} \\
\quad \text { via RIA }\end{array}$ & $\begin{array}{l}\text { No association was observed between } 25(\mathrm{OH}) \mathrm{D} \\
\text { levels and psychometric measures in both } \\
\text { adolescent and adult groups. In the elderly } \\
\text { group however, those within the highest } \\
25(\mathrm{OH}) \text {-quintile showed learning and memory } \\
\text { impairments }\end{array}$ \\
\hline $\begin{array}{l}\text { Maddock et al. } \\
\quad(2014)^{(82)}\end{array}$ & Cohort & $\begin{array}{l}6496 \text { participants from the } \\
1958 \text { British Cohort }\end{array}$ & $\begin{array}{l}\text { Verbal memory and fluency; } \\
\text { processing speed }\end{array}$ & $\begin{array}{l}\text { 5-year follow-up } \\
\text { (Baseline: } 45 \text { years } \\
\text { of age) }\end{array}$ & $\begin{array}{l}\text { Serum } 25(\mathrm{OH}) \mathrm{D} \\
\text { via automated } \\
\text { enzyme } \\
\text { immunoassay } \\
\text { (OCTEIA) }\end{array}$ & $\begin{array}{l}\text { Participants with both low and high serum } \\
25(\mathrm{OH}) \mathrm{D} \text { concentrations performed } \\
\text { significantly worse on specific cognitive } \\
\text { domains; immediate word recall }\end{array}$ \\
\hline $\begin{array}{l}\text { Schneider et al. } \\
\qquad(2018)^{(90)}\end{array}$ & Cohort & $\begin{array}{l}13044 \text { participants from the } \\
\text { Atherosclerosis Risk in } \\
\text { Communities Brain MRI } \\
\text { Study (baseline age } \\
45-65 \text { years) }\end{array}$ & $\begin{array}{l}\text { Recent memory and verbal } \\
\text { learning; processing speed; } \\
\text { executive function }\end{array}$ & $\begin{array}{l}\text { 20-year follow-up } \\
\text { (mean age of } \\
57 \text { years at } \\
\text { baseline) }\end{array}$ & $\begin{array}{l}\text { Serum } 25(\mathrm{OH}) \mathrm{D} \text { by } \\
\text { liquid } \\
\text { chromatography- } \\
\text { tandem MS }\end{array}$ & $\begin{array}{l}\text { Over a } 20 \text {-year follow-up period, there were no } \\
\text { significant associations between lower serum } \\
25(\mathrm{OH}) \mathrm{D} \text { concentrations at midlife with greater } \\
\text { rate of cognitive deterioration }\end{array}$ \\
\hline
\end{tabular}


from seventeen observational cohort studies, including over 170000 participants, concluded no evidence of an association between serum $25(\mathrm{OH}) \mathrm{D}$ concentration as a causal factor for cognitive performance in later life. Similarly, a 4.5-year longitudinal male ageing study by Overman et $a{ }^{(95)}$ found no association between serum $25(\mathrm{OH}) \mathrm{D}$ and $1,25(\mathrm{OH})_{2} \mathrm{D}_{3}$ concentrations and multiple cognitive subdomains in 3369 men aged between 40 and 79 years of age.

Vitamin D supplementation and cognitive function. Results from RCT linking vit-D deficiency and cognitive decline have not been promising ${ }^{(89,96,97)}$ (Table 1). There was no benefit on cognition or memory realised in vit-D-deficient older participants supplemented with vit- $\mathrm{D}^{(92,97,98)}$. Results from the Women's Health Initiative study found that vit-D and Ca supplementation over a period of 8 years had no beneficial effects on cognition $^{(99)}$. Studies by Stein et al ${ }^{(97)}$ show that supraphysiological levels of vit-D did not confer beneficial effects in cognitive performance in individuals with mild-moderate Alzheimer's disease. A study by Rossom et al. ${ }^{(92)}$ failed to demonstrate positive effects of vit-D supplementation in attenuating cognitive dysfunction, or on lowering the risk of dementia when compared with placebo. Moreover, Castle and colleagues recently reported on the differential dosage effects of vit-D on specific cognitive domains in healthy, post-menopausal women whereby higher doses were found associated with poorer reaction time and measures of learning and memory ${ }^{(83)}$. Furthermore, a recent literature review by Landel et $a l^{(72)}$ determined that there was no solid evidence to suggest that exogenous supplementation of vit-D improves cognition in those who already have sufficient serum levels of vit-D. Collectively, results of RCT do not consistently suggest postive effects of exogenous vit-D on cognitive performance.

\section{Hypervitaminosis-D and cognitive performance}

Recent studies suggest cognitive impairment may indeed also be indicated in individuals with greater levels of serum vit-D, especially those taking vit-D supplements. Granic et al. ${ }^{(25)}$ reported that both the lowest and highest season-specific serum $25(\mathrm{OH}) \mathrm{D}$ quartiles had increased risk of cognitive impairment compared with those in the middle quartiles adjusted for socio-demographic, health and lifestyle confounders. An increased risk of poorer global cognition and attention amongst those in the highest quartile was observed, specifically in users of vit-D supplements.

Earlier reports by McGrath et $a l^{(81)}$ did not find significant associations between lower vit-D status and neurocognitive performance in adolescent and adult groups. However, there was a significant association between vit-D levels and cognitive performance in the elderly group, demonstrating unexpected results that those with increased levels of vit-D, particularly those taking vit-D supplements performing worse in learning and memory measures. Consistent with these findings, Lam et al. ${ }^{(100)}$ found an association between higher serum vit-D status and poorer verbal episodic memory performance in those with normal Ca-parathyroid hormone homeostasis in middle-aged and older individuals. 
Whilst a significant number of cross-sectional, epidemiological and population studies have explored the association of serum vit-D status and cognition, mechanistic studies are lacking. Cell studies by Brown et al. ${ }^{(101)}$ demonstrated that vit-D treatment of cultured hippocampal cells can initiate cellular apoptosis and similar findings have been indicated in cancerous cell lines ${ }^{(102-104)}$. Excessive activation of the VDR causes gene transcription associated with mitochondrial export of cytochrome $\mathrm{C}$ and subsequent cleavage of caspase-9, which consequently promotes DNA fragmentation and thereby $\operatorname{apoptosis}^{(105)}$.

Vitamin D homeostasis and ageing. Population studies exploring the association between vit-D homeostasis and cognitive capacity in late-aged individuals may be confounded by 'reverse causation' due to lifestyle changes and immobility $^{(106-109)}$. Moreover, the ability to synthesise endogenous vit-D within the epidermis or to activate $25(\mathrm{OH}) \mathrm{D}$ may be age-dependent ${ }^{(110)}$. Paradoxical reports have been published with some studies suggesting increased, decreased or unchanged vit-D metabolite concentrations with ageing in both preclinical and clinical studies ${ }^{(35,110,111)}$. In addition to putative age-associated changes in peripheral biosynthetic and conversion of vit-D metabolites, pre-clinical and clinical data indicate that there is a marked reduction in intestinal, kidney and skeletal responsiveness to $1,25(\mathrm{OH})_{2} \mathrm{D}$ with age through mechanisms which are presently unclear $^{(35)}$. Several studies have demonstrated a reduction in intestinal VDR expression ${ }^{(112-114)}$ with ageing in both animal and human studies, although others have reported no change ${ }^{(115,116)}$. A putative age-related diminished intestinal responsiveness to $1,25(\mathrm{OH})_{2} \mathrm{D}_{3}$ may be associated with modified recruitment of VDR, VDR co-activators or epigenetic changes ${ }^{(35)}$. Presently, no studies have investigated cerebral vit-D homeostasis, receptors or 'responsiveness' in the context of ageing, an important consideration in the context of CNS function and cognitive performance.

Hypervitaminosis-D and accelerated ageing. The global prevalence of hypovitaminosis-D during ageing is well documented $^{(117)}$. However, possible effects of hypervitaminosis-D on the ageing process are not yet clear ${ }^{(27)}$. Based on the strict regulation of vit-D activation, hypervitaminosis-D is rare in humans based on dietary sources. Nonetheless, vit-D supplementation has been associated with early ageing, hypercalcaemia, cardiovascular complications (vascular-related) and early death, supporting the association between hypervitaminosis-D and accelerated ageing ${ }^{(118)}$. Two genes of interest in this area of study are FGF-23, involved in suppression of renal expression of $1,25(\mathrm{OH})_{2} \mathrm{D}_{3}$, resulting in decreased production of calcitriol, and KLOTHO; a membrane protein involved with cellular functions and cell-matrix interactions ${ }^{(119)}$. Recent in vivo genetic-manipulation studies have shown increased serum levels of vit-D and altered mineral-ion homeostasis in mice that lack either FGF-23 or KLOTHO genes ${ }^{(27)}$. Furthermore, hypervitaminosis-D in these mutant mice exhibits an accelerated ageing phenotype ${ }^{(26)}$. Genetic ablation of FGF-23 or KLOTHO genes in other rodent models results in hypervitaminosis-D, hypercalcaemia and hyperphosphataemia, corresponding with a phenotype consistent with premature ageing ${ }^{(26)}$.
Remarkably, Tsujikawa et al. ${ }^{(120)}$ reported that dietary restriction of vit-D reverses the premature-ageing phenotypes and indeed prolongs life in the KLOTHO knockout mouse model, an observation now reported in other studies. Polymorphisms in the human KLOTHO gene have also been associated with the occurrence of a number of age-related pathologies such as $\mathrm{CVD}^{(121)}$. These findings provide strong evidence that hypervitaminosis- $\mathrm{D}$ may be causally associated with the ageing process.

\section{Vitamin D receptor genetic polymorphisms and cognitive function}

Genetic variability for vit-D metabolism may be associated for an individual's susceptibility to cognitive decline. Polymorphisms of the VDR gene have been shown to influence the susceptibility to age-related changes in cognitive functioning and progression of neurodegenerative diseases such as Alzheimer's disease, mild cognitive impairment, Parkinson's disease and implicated with cognitive function ${ }^{(122,123)}$. However, literature contributing to the delineation of the putative metabolic pathways that result in cognitive dysfunction is varied and inconclusive.

The VDR is synthesised by the VDR gene, located on chromosome 12 and composed of nine exons ${ }^{(124)}$, of which several genetic variations have been recognised. Approximately $1 \%$ of the population has a DNA gene variation of the $\mathrm{VDR}^{(125)}$. These genetic alterations can lead to significant defects on gene activation, affecting cell proliferation, mineral and hormonal metabolism and immune function. The most investigated polymorphisms of the VDR gene include Cdx-2, FokI, BsmI, ApaI and Taq1 and are often associated with phenotypes involving bone mineral density, osteoporotic fracture risk and cancer ${ }^{(122,123)}$.

Kuningas et al. ${ }^{(123)}$ observed a significant decline in cognitive performance in those carrying the BsmI and Taq1 polymorphisms; however, no cognitive deficit was observed in participants carrying the Cdx-2 or FokI polymorphisms (Table 2 for summary of studies to date). Interestingly, individuals with the ApaI polymorphisms performed better on tests measuring processing speed, attention and memory. These findings complemented those reported by Uitterlinden and colleagues in $2004^{(126)}$. In contrast, Leymann et al. ${ }^{(127)}$ found the ApaI VDR polymorphisms to be significantly associated with cognitive decline and increased risk of $\mathrm{AD}$, particularly in people under 75 years. Similarly, Keyimu et al. ${ }^{(128)}$ found both BsmI and ApaI polymorphisms significantly associated with an increased risk of mild cognitive impairment in a cohort of elderly Uygur people. A 2015 meta-analysis, totalling seven studies with 2034 Parkinson's disease cases and 2432 healthy controls, found polymorphisms of ApaI, Bsm1 and Taq1 were not associated with the susceptibility to Parkinson's disease, while the FokI (C and $\mathrm{T}$ allele) polymorphisms were associated with an increased risk in Parkinson's disease ${ }^{(129)}$.

In a recent study, Beydoun et al. ${ }^{(130)}$ evaluated associations of VDR polymorphisms (Cdx, BsmI, ApaI and Taq1) and LDL receptor, megalin, with a decline in longitudinal cognitive performance in 1024 healthy African American adults. Megalin is expressed in endothelial cells of the BBB and potentially mediates vit-D transport from the blood to brain parenchyma (Fig. 1). Beydoun and others have reported that VDR (BsmI/ApaI/Taq1) 
Table 2. Summary of cross-sectional and cohort studies exploring the link between vitamin D receptor (VDR) gene polymorphisms and cognitive osutcomes

\begin{tabular}{|c|c|c|c|c|c|}
\hline Reference/author/year & Sample participants/size & Study design & $\begin{array}{l}\text { VDR gene } \\
\text { polymorphisms } \\
\text { investigated }\end{array}$ & Study focus & Outcomes \\
\hline $\begin{array}{l}\text { Pettersen et al. } \\
\quad(2015)^{(122)}\end{array}$ & Healthy adults ( $n 78$ ) & Cross-sectional & Fokl & $\begin{array}{l}\text { The relationship between the VDR Fokl } \\
\text { genotype, serum } 25(\mathrm{OH}) \mathrm{D} \text { levels and } \\
\text { cognitive functioning was investigated }\end{array}$ & $\begin{array}{l}\text { Polymorphisms in the FokI VDR gene were } \\
\text { associated with non-verbal executive task } \\
\text { and global cognitive performance, } \\
\text { independent of serum } 25(\mathrm{OH}) \mathrm{D} \text { levels }\end{array}$ \\
\hline $\begin{array}{l}\text { Kuningas et al. } \\
\qquad(2009)^{(123)}\end{array}$ & $\begin{array}{l}563 \text { participants }>85 \text {-years of age } \\
\text { from the Leiden } 85 \text {-plus study }\end{array}$ & Cohort & $\begin{array}{l}\text { Cdx-2; Fokl; Bsml; } \\
\text { Apal; Taq1 }\end{array}$ & $\begin{array}{l}\text { This study investigated whether genetic } \\
\text { variance in the VDR gene is associated } \\
\text { with cognitive functioning and depressive } \\
\text { symptoms }\end{array}$ & $\begin{array}{l}\text { Genetic variance in the VDR gene influences } \\
\text { the susceptibility to age-related changes in } \\
\text { cognitive performance. Carriers of Bsml } \\
\text { and Taq1 polymorphisms exhibited poorer } \\
\text { cognitive functioning }\end{array}$ \\
\hline Gatto et al. $(2016)^{(137)}$ & $\begin{array}{l}\text { Non-Hispanic Caucasian PD } \\
\text { participants }(n 190) \text { from the } \\
\text { Parkinson Environment Gene } \\
\text { study (average age of diagnosis } \\
67.4 \text { years) }\end{array}$ & Cohort & Fokl & $\begin{array}{l}\text { Explored the relationship of VDR } \\
\text { polymorphisms and cognitive decline in } \\
\text { individuals with PD (average follow-up of } \\
7.1 \text { years) }\end{array}$ & $\begin{array}{l}\text { Fokl, a functional VDR polymorphism, was } \\
\text { associated with cognitive decline in PD } \\
\text { individuals. Each additional copy of the } \\
\text { Fokl A allele was associated with a } \\
\text { significant decrease in the cognitive test } \\
\text { score per year of follow-up }\end{array}$ \\
\hline $\begin{array}{l}\text { Lehmann et al. } \\
\qquad(2011)^{(127)}\end{array}$ & $\begin{array}{l}\text { Caucasian participants with } \\
\text { Alzheimer's disease }(n \text { 255) and } \\
\text { healthy elderly controls ( } n \text { 260) } \\
\text { (mean age } 78.4 \text { years) }\end{array}$ & Cohort & Apal and Taq1 & $\begin{array}{l}\text { This study used DNA from Alzheimer's } \\
\text { disease cases and cognitively screened } \\
\text { elderly controls from the longitudinal } \\
\text { cohort of the Oxford Project to investigate } \\
\text { the relationship between two VDR } \\
\text { polymorphisms and memory and ageing }\end{array}$ & $\begin{array}{l}\text { Apal T and Taq1 VDR polymorphisms were } \\
\text { significantly associated with cognitive } \\
\text { decline and increased risk of Alzheimer's } \\
\text { disease }\end{array}$ \\
\hline Keyimu et al. $(2014)^{(128)}$ & $\begin{array}{l}124 \text { mildly cognitive impaired } \\
\text { participants and } 124 \text { healthy } \\
\text { controls }\end{array}$ & Cohort & Apal and Bsml & $\begin{array}{l}\text { This study explores the relationship } \\
\text { between VDR gene polymorphisms, Apal, } \\
\text { Bsml and risk of mild cognitive } \\
\text { impairment }\end{array}$ & $\begin{array}{l}\text { Alleles associated with both Bsml and Apal } \\
\text { polymorphisms, T allele and A allele, } \\
\text { respectively, were significantly associated } \\
\text { with an increased risk of mild cognitive } \\
\text { impairment }\end{array}$ \\
\hline Beydoun et al. $(2017)^{(121)}$ & $\begin{array}{l}1024 \text { healthy African American adults } \\
\text { (mean age } 52 \text { years) }\end{array}$ & Cohort & $\begin{array}{l}\text { VDR polymorphisms; } \\
\text { Bsml; Apal; Taq1; } \\
\text { and megalin }\end{array}$ & $\begin{array}{l}\text { This study explored the putative } \\
\text { associations of VDR and megalin } \\
\text { polymorphisms with longitudinal changes } \\
\text { in cognitive function (follow-up ranged } \\
\text { from } 1 \text { to } 8 \text { years; mean of approx. } \\
4 \text { years) }\end{array}$ & $\begin{array}{l}\text { Bsml/Apal/Taq1 and megalin gene } \\
\text { polymorphisms altered age-related } \\
\text { cognitive pathways, specifically in global } \\
\text { mental status, verbal fluency, visual and } \\
\text { working memory and executive function }\end{array}$ \\
\hline Beydoun et al. (2012) $)^{(131)}$ & $\begin{array}{l}\text { Cohort study of } 702 \text { non-Hispanic } \\
\text { white participants at risk of mild } \\
\text { cognitive impairment or dementia } \\
\text { (mean age of } 52.3 \text { years) }\end{array}$ & Cohort & $\begin{array}{l}\text { VDR polymorphisms; } \\
\text { Bsml; Apal; Taq1; } \\
\text { and megalin }\end{array}$ & $\begin{array}{l}\text { Associations between single nucleotide } \\
\text { polymorphisms of VDR and megalin were } \\
\text { explored in conjunction with longitudinal } \\
\text { cognitive performance }\end{array}$ & $\begin{array}{l}\text { VDR and megalin gene polymorphisms were } \\
\text { associated with longitudinal changes in } \\
\text { cognitive decline, in } \\
\text { a sex-specific manner }\end{array}$ \\
\hline
\end{tabular}

25(OH)D, 25-hydroxyvitamin D; PD, Parkinson's disease. 
and megalin gene polymorphisms to correlate with age-related cognitive decline, specifically in performance tasks assessing global mental status, verbal fluency, visual/working memory and executive function ${ }^{(123,131-134)}$. Studies investigating VDR polymorphisms and cognitive indices are heterogeneic, inconclusive and exacerbated by the confounder of uncertainy in plasma and cerebral homeostasis of vit- $\mathrm{D}^{(135)}$

Genetic and environmental interactions regulating vitamin$D$ homeostasis, vitamin $D$ receptor polymorphisms and cognitive performance. The relationship between VDR polymorphisms, vit-D metabolite concentrations and CNS function remains unclear ${ }^{(136)}$. It has been demonstrated by multiple researchers that expression and functionality of VDR polymorphisms to transactivate specific DNA gene sequences are regulated by both genetics, environment and abundance of bioactive vit- $\mathrm{D}^{(128,134,137)}$. For example, Wilkinson et al. ${ }^{(138)}$ observed the TT/Tt VDR genotype of Taq1 polymorphism was associated with tuberculosis in a UK Indian population, but only in a vit-D-deficient state. Wong et al $^{(139)}$ found an individual's susceptibility to colon cancer doubles when genotyped with ff FokI polymorphisms when consuming a low $\mathrm{Ca}$ (increased $1,25(\mathrm{OH})_{2} \mathrm{D}_{3}$ synthesis) in comparison with $\mathrm{FF}$ genotypes. Collectively, it is apparent the impact of VDR polymorphisms on the function of the VDR may be strongly influenced by an individual's vit-D status and thereby associated disease risk ${ }^{(135)}$. By extension, similar effects may be indicated with respect to CNS function and cognition.

Whilst plasma insufficiency of vit-D concomitant with expression of selected VDR isoforms has been associated with Alzheimer's disease and cognitive decline ${ }^{(122)}$, the possibility of strong associations between vit-D concentrations above normal physiological levels and VDR polymorphisms remains to be investigated. Interestingly, some studies have shown that FokI polymorphisms change the VDR translation initiation site and alter its functional properties, producing multiple isoforms of the receptor which influence transcription factor expression ${ }^{(135,140)}$. The $f$ allele ( $T$ nucleotide) on the FokI gene produces a longer VDR protein which is proposed to be less active in influencing transcription factor and thus affecting downstream effects ${ }^{(135)}$. Conversely, the F allele ( $\mathrm{C}$ nucleotide) on the FokI gene results in a VDR protein truncated by three amino acids, which is more effective in activating transcription factor ${ }^{(135,141,142)}$. Orton et al ${ }^{(143)}$ found lower concentrations of $25(\mathrm{OH}) \mathrm{D}(25 \cdot 8 \pm 2.2 \mathrm{ng} / \mathrm{ml})$ when coding for homozygous genotypes for the shorter VDR isoform, compared with greater $25(\mathrm{OH}) \mathrm{D}$ concentrations $(33.3 \pm 1.6 \mathrm{ng} / \mathrm{ml})$ when coding for the longer VDR isoform in heterozygous and homozygous genotypes.

\section{Vitamin D and neurovascular inflammation}

The BBB is a semipermeable membrane comprising the cerebrovascular wall which separates the blood serum from the brain parenchyma ${ }^{(144)}$. The unique endothelial junctions of the BBB ensure the tight regulation of substances entering the $\mathrm{CNS}^{(145-147)}$. BBB dysfunction is characterised by compromised cerebrovascular integrity leading to unregulated extravasation of serum constituents into the brain parenchyma. An increasing number of studies suggest that impairment of cerebral capillaries at the endothelial cell may be a major risk factor prior to the progression of clinical cognitive dysfunction $^{(24,144,148)}$. Recent experimental and clinical studies have shown therapeutic benefit in attenuating progression of neurodegeneration/cognitive decline if cerebrovascular disturbances are attenuated $^{(149,150)}$.

Lam et al. ${ }^{(24)}$ demonstrated that vit-D-enriched diets resulted in increased brain capillary permeability and neuroinflammation in a dose-dependent manner and independent of serum Ca homeostasis, or suppression of parathyroid hormone. Lam's study is the first to demonstrate that provision of exogenous vit-D supplementation above ordinary physiological levels has significant cerebrovascular-regulating properties. Furthermore, Durk et al. ${ }^{(151)}$ recently investigated VDR expression on cerebral endothelial cells, which when activated by its bioactive ligand, $1,25(\mathrm{OH})_{2} \mathrm{D}_{3}$ was found to alter the kinetics of endothelial p-glycoprotein expression and its substrates. As p-glycoprotein is an ATP-driven efflux pump and a major blockade in the prevention of small-molecule delivery across the BBB and into the brain ${ }^{(152)}$, Durk's findings, whilst not directly implicating vit-D and the regulation of cerebral capillary function, certainly support this notion that vit-D can influence BBB permeability.

High-dose vit-D supplementation has been associated with an increased systemic inflammatory phenotype in concert with increased colitis susceptibility in animal studies ${ }^{(153)}$. In alignment with the pro-inflammatory phenotype exacerbated by high-dose vit-D intake, a recent study by Krementsov et al. ${ }^{(154)}$ reported intriguing results in a pre-clinical model of autoimmune neuroinflammation (multiple sclerosis) whereby high-dose vit-D supplementation unexpectedly exacerbated disease susceptibility, in a sex- and genotype-specific manner. It is apparent that present evidence suggests restoration of vit-D homeostasis to sufficient levels from a vit-D-deficient state has been shown to ameliorate CNS oxidative stress, mitochondrial dysfunction, neuroinflammation and apoptosis that culminate in neurodegeneration $^{(155-159)}$. However to date, no studies have reported the effects of exaggerated vit-D metabolism on the aforementioned mechanisms on the CNS, and indeed, warrants further investigation.

\section{Clinical considerations: reference serum vitamin D concentration}

The definition for appropriate serum vit-D ranges remains controversial $^{(160)}$. The U.S. Institute of Medicine states insufficient vit-D levels are defined by $25(\mathrm{OH}) \mathrm{D}$ levels below $50 \mathrm{nmol} / \mathrm{l}^{(161)}$, the Endocrine Society whom reports insufficiency of $25(\mathrm{OH}) \mathrm{D}$ below $72.5 \mathrm{nmol} / \mathrm{l}^{(162)}$, whilst the Vitamin D Council refers to insufficiency at a concentration below $97.5 \mathrm{nmol} / 1$ of circulating $25(\mathrm{OH}) \mathrm{D}^{(29)}$. There are also meta-analyses, RCT and observational studies that suggest sufficient vit-D levels are approximately $100 \mathrm{nmol} / \mathrm{l}^{(163-166)}$, a concentration that some organisations would dispute and suggest may be potentially reaching toxic levels ${ }^{(162)}$.

Ross et $a l .{ }^{(167)}$ and a more recent study by Manson et $a l^{(11)}$ state vit-D recommendations are based on bone health, while benefits for other non-skeletal systems, such as the brain, remain 
unclear. A diagnosis of vit-D deficiency is generally based on the findings that supplementing with $15-20 \mu \mathrm{g}$ of vit-D/d (Institute of Medicine RDA for adults) fails to increase vit-D serum levels above $50 \mathrm{nmol} / 1$ in a population of North America. Manson et al. suggests, however, that a vit-D level of $40 \mathrm{nmol} / \mathrm{l}$ would serve the requirement of half of the North American population, whilst vit-D levels of $50 \mathrm{nmol} / 1$ are considered adequate to the majority of the indicated population. Presently, it is difficult to robustly define a physiological reference range, particularly in context of optimal CNS function, given the numerous factors that may influence vit-D status and response. Moreover, there is a paucity of studies which consider potential adverse effects associated with persistently higher blood or tissue concentration of bioactive vit-D metabolites. The importance of defining a suitable range and appropriate biomarker to accurately reflect vit-D levels is urgently needed.

\section{Measurement of vitamin D homeostasis}

Blood vit-D homestasis is indicative of $25(\mathrm{OH}) \mathrm{D}$ bound to VDBP ( $85 \%), 25(\mathrm{OH}) \mathrm{D}$ bound to albumin $(15 \%)$ and unbound (free) 25(OH)D (Fig. 1) ${ }^{(168)}$.

Serum $25(\mathrm{OH}) \mathrm{D}$ is ordinarily used as the surrogate biomarker of homeostasis based on its long half-life, a critical intermediary in the utilisation of $1,25(\mathrm{OH}) \mathrm{D}$ by the body, and because tissue level hydroxylase enzymes, such as CYP27B1, function below their $\mathrm{K}_{\mathrm{m}}$ values and are below detectable limits. However, recent studies have challenged the validity of utilising $25(\mathrm{OH}) \mathrm{D}$ as a surrogate marker of active biological effects illicited as a consequence of $1,25 \mathrm{OHD}$ binding to high-affinity receptors ${ }^{(169,170)}$. The recent updated international recommendations by a panel of 12 vit-D experts concluded that $25(\mathrm{OH}) \mathrm{D}$ was not an appropriate marker of vit-D physiological homeostasis ${ }^{(14)}$

Hilger et $a l^{(169)}$ recently conducted a systematic review of vit-D status in global populations in which 195 studies were analysed from forty-four countries, involving over 168000 participants. The study reported substantial variability in mean serum $25(\mathrm{OH}) \mathrm{D}$ concentrations (range $4.9-136.2 \mathrm{nmol} / \mathrm{l}$ ) within the same geographical regions around the world. Clearly on a global scale, there are huge discrepancies in using $25(\mathrm{OH}) \mathrm{D}$ metabolite alone as a reflection of total vit-D status ${ }^{(162,167)}$.

Common methods to assess vit-D metabolites and homeostasis include MS and high-pressure liquid chromatography (HPLC-MS), enzyme immunoassays, competitive protein binding assays, RIA, chemiluminescent immunoassays and automated chemiluminescence protein-binding assays ${ }^{(171,172)}$. Clinical measures are not harmonised internationally making appropriate reference ranges difficult to compare (Table 1). Due to the significant assay variation in $25(\mathrm{OH}) \mathrm{D}$ measurement and substantial interassay and laboratory variability ${ }^{(173-175)}$, unsubstantiated assumptions for $25(\mathrm{OH}) \mathrm{D}$ as a robust marker of vit-D status have been realised $^{(176)}$.

The Vitamin D External Quality Assessment Scheme is the world's largest specialist scheme for assessing and evaluating the reliability of $25(\mathrm{OH}) \mathrm{D}$ assays and has been in operation since 1989. As of January 2017, the data collected by Vitamin D External Quality Assessment Scheme was a contribution of fifty-six countries and covered analysis from approximately thirty different assay methods ${ }^{(176)}$. Indeed, multiple studies, including reports from Vitamin D External Quality Assessment Scheme, have indicated a great deal of variability between different $25(\mathrm{OH}) \mathrm{D}$ metabolite assays as well as inter-laboratory disagreement ${ }^{(173,177-182)}$.

Snellman et $a l .{ }^{(171)}$ investigated the precision and accuracy of three common commercially available assays (HPLC-MS, RIA and chemiluminescent immunoassays) with diverse results. Researchers accounted for a multitude of confounders such as age, sex, ethnicity, season, altitude, geography, as well as limiting genetic variability, in their cohort of Swedish twins ( $n$ 204). Mean 25(OH)D concentrations between assays showed up to $30 \%$ ( $25 \mathrm{nmol} / \mathrm{l}$ ) variability (HPLC-MS $85 \mathrm{nmol} / \mathrm{l}$; RIA $70 \mathrm{nmol} / \mathrm{l}$; chemiluminescent immunoassays $60 \mathrm{nmol} / \mathrm{l})$. Moreover, Black et al. $^{(183)}$ investigated inter-laboratory $25(\mathrm{OH}) \mathrm{D}$ concentrations using Australian participants ( $n$ 840) from three different laboratories. The three laboratories used DiaSorin Liaison and HPLCMS-based 25(OH)D detection assays, which were analysed against a certified laboratory using a standardised HPLC-MS-based assay. Results from all four laboratories were wide-ranging. Researchers are now engaged in an international effort to suspend metaanalyses publications on whose methodologies are based on unstandardised $25(\mathrm{OH}) \mathrm{D}$ data ${ }^{(160)}$. According to the National Institute of Health, Office of Dietary Supplements USA (2017), an international effort to standardise the measurement of $25(\mathrm{OH}) \mathrm{D}$ and its metabolites is currently being led by the Vitamin D Standardization Program ${ }^{(184)}$.

Contemporary liquid chromatography-MS (LC-MS/MS) analytical methods have been developed and validated to simultaneously quantify a comprehensive panel of vit-D compounds in human serum. Historically, the extraction and chromatographing of vit-D compounds have been particulary challenging due to the range of polarities and different molecular moieties. However, in the recent years, optimised precipitation and separation techniques have produced high-sensitivity, recovery and resolution results which can quantitate up to fifteen vit-D compounds (bioactive, inactive, catabolites) and indeed, an appropriate alternative to standardise analysis of vit-D status ${ }^{(185,186)}$.

In cases of suspected clinical vit-D deficiency, physicians generally recommend either ergocalciferol $\left(v i t-\mathrm{D}_{2}\right)$ or cholecalciferol (vit- $\mathrm{D}_{3}$ ) supplementation ${ }^{(187)}$. Measurement of total vit-D status includes circulating serum calcifediol $(25(\mathrm{OH}) \mathrm{D})$ and metabolites $25(\mathrm{OH}) \mathrm{D}_{2}$ and $25(\mathrm{OH}) \mathrm{D}_{3}$; however, not all the immunoassays are able to detect $25(\mathrm{OH}) \mathrm{D}_{2}$ in clinical practice ${ }^{(33)}$. Nonetheless, Tripkovic et al. ${ }^{(188)}$ conducted a metaanalysis and systematic review of RCT from 1966 to 2011 that directly compared the effect both vit- $\mathrm{D}_{2}$ and vit- $\mathrm{D}_{3}$ on raising circulating serum $25(\mathrm{OH}) \mathrm{D}_{2}$ or $25(\mathrm{OH}) \mathrm{D}_{3}$ levels, respectively. Significantly higher $25(\mathrm{OH}) \mathrm{D}_{3}$ levels than $25(\mathrm{OH}) \mathrm{D}_{2}$ were achieved when participants were given $20 \mu \mathrm{g}$ of vit- $\mathrm{D}_{3}$, compared with those given $20 \mu \mathrm{g}$ of vit- $\mathrm{D}_{2}$, findings replicated in subsequent studies ${ }^{(189,190)}$. Swanson et al $^{(191)}$ sought to quantify and examine the associations between $25(\mathrm{OH}) \mathrm{D}_{2}$, and $25(\mathrm{OH}) \mathrm{D}_{3}$, with their bioactive forms $1,25(\mathrm{OH})_{2} \mathrm{D}_{2}$, and $1,25(\mathrm{OH})_{2} \mathrm{D}_{3}$, respectively, in a large cohort of older men $(n$ 679) to better understand how $25(\mathrm{OH}) \mathrm{D}_{2}$ relates to the other vit-D metabolites. Interestingly, greater levels of $25(\mathrm{OH}) \mathrm{D}_{2}$ were associated with 
lower levels of both $25(\mathrm{OH}) \mathrm{D}_{3}$ and biologically active $1,25(\mathrm{OH})_{2} \mathrm{D}_{3}$. Furthermore, $25(\mathrm{OH}) \mathrm{D}_{2}$ was not found to be associated with higher total levels of $25(\mathrm{OH}) \mathrm{D}$ or physiologically relevant $1,25(\mathrm{OH})_{2} \mathrm{D}$. Collectively, the findings suggest that differences between $25(\mathrm{OH}) \mathrm{D}_{2}$ and $25(\mathrm{OH}) \mathrm{D}_{3}$ are due to dissimilar affinities for the VDR, which appears to be linked to an extra step of 24-hydroxylation that inactivates $1,25(\mathrm{OH})_{2} \mathrm{D}^{(192)}$. Additionally, it is thought that $25(\mathrm{OH}) \mathrm{D}_{3}$ is the preferred substrate for hepatic 25-hydroxylase enzyme, CY2R1, which in combination may alter the rate of 24-hydroxylation ${ }^{(188)}$.

Interestingly, Jones et al. ${ }^{(193)}$ compared the serum half-lives of $25(\mathrm{OH}) \mathrm{D}_{2}$ and $25(\mathrm{OH}) \mathrm{D}_{3}$ in two separate populations from the UK and Gambia, Africa ( $n$ 36), with differing 25(OH)D status. Results showed that not only was the half-life of $25(\mathrm{OH}) \mathrm{D}_{2}$ shorter than $25(\mathrm{OH}) \mathrm{D}_{3}$ but also the half-lives were affected by VDBP concentration and genotype.

\section{Vitamin $\mathrm{D}$ binding protein measurement and} polymorphisms

Numerous tissues express the VDBP with liver as the major source for plasma abundance. However, VDBP expression has also been demonstrated in the brain, spinal cord, kidney, skeletal muscle, heart, lung, intestine and bone ${ }^{(194,195)}$. The VDBP can be determined in blood serum, cerebrospinal fluid, saliva, seminal fluid and breast milk ${ }^{(196)}$. VDBP is the primary chaperone protein for $25(\mathrm{OH}) \mathrm{D}$ due to higher affinity compared with albumin ${ }^{(197)}$. The free hormone hypothesis postulates that protein-bound hormones are biologically inactive, while unbound hormones are biologically free to exert their physiological activity ${ }^{(198)}$.

Notionally, only $1 \%$ of total $25(\mathrm{OH}) \mathrm{D}$ concentration is available for conversion to the bioactive $1,25(\mathrm{OH}) \mathrm{D}^{(168)}$. VDBP serves as a sink for 25(OHD) and may be critical in the context of conversion to $1,25(\mathrm{OH}) \mathrm{D}^{(197)}$. There are three forms of VDBP polymorphisms that exist, originally referred to as GC1F, GC1S and GC2. These allow for six allelic phenotypes (1s/1s, 1s/ 1f, 1s/2, 1f/1f, 1f/2 and 2/2) ${ }^{(199)}$. These phenotypes can be identified by genotyping for the two SNP, rs7041 and rs4588, in the GC gene $^{(200)}$. These polymorphisms occur at a diverse range of frequencies among different races and ethnicities ${ }^{(197)}$. Allelic variants of VDBP are at varied concentrations within blood $^{(201)}$ and different binding affinities for $25(\mathrm{OH}) \mathrm{D}$ and $1,25(\mathrm{OH}) \mathrm{D}^{(202,203)}$. Engelman et al. ${ }^{(204)}$ showed that homozygosity for the CG1F allele occurred in $53 \%$ of African Americans but only $6 \%$ of Caucasians and $13 \%$ of Hispanics. Interestingly, over $50 \%$ of African Americans has a vit-D deficiency diagnosis, yet their low 25(OH)D concentrations do not appear to be linked with a higher risk of bone fractures, as they do in white Americans ${ }^{(205)}$. Consistent with the latter, Powe et al. ${ }^{(206)}$ found racial, ethnic variation in VDBP polymorphism concentrations in black and white Americans and showed difference in total $25(\mathrm{OH}) \mathrm{D}$, but comparable abundance of bioavailable $25(\mathrm{OH})$ D. Harris ${ }^{(207)}$ previously compared vit-D metabolites in American Caucasians and African Americans, indicating African Americans have higher circulating concentrations of the bioactive vit-D at a given level of $25(\mathrm{OH}) \mathrm{D}$ compared with
Caucasians. In studies by Lutsey et al. ${ }^{(208)}$, they reported lower VDBP levels in African Americans in comparison with Caucasians were associated with a higher concentration of 25(OH)D. Furthermore, Sinottee et al. ${ }^{(209)}$ evaluated the association between VDBP polymorphisms and 25(OH)D concentrations in white premenopausal Caucasian French women ( $n 741)$ and concluded that circulating $25(\mathrm{OH}) \mathrm{D}$ is highly correlated with VDBP polymorphisms. Other studies investigating VDBP polymorphisms have also found varied vit-D metabolite concentrations amongst race and ethnic groups ${ }^{(204,210-212)}$.

In Troms $\varnothing$, Northern Norway, longitudinal population-based health surveys covering general, medical and pathological information have been conducted at 6-7years intervals since $1974^{(200)}$. Thus far, blood samples have totalled 27000 participants and genotyping for VDBP polymorphisms has been undertaken in 11704 participants. The prevalence in VDBP polymorphisms ranged between 4.4 and $30.9 \%$ within population. Findings clearly demonstrate that $25(\mathrm{OH}) \mathrm{D}$ levels were not only dependent on VDBP and albumin concentrations but also significantly associated with VDBP polymorphisms. Additionally, factors influencing VDBP concentration and ultimately, VDBP polymorphisms and vit-D status, include age and $\operatorname{sex}^{(213,214)}$, diurnal rhythms ${ }^{(215)}$ and obesity ${ }^{(216,217)}$. Recent studies have further demonstrated that serum VDBP concentration is decreased in pathological states including, type 1 diabetes mellitus $^{(218)}$, chronic liver disease ${ }^{(168,219)}$ and renal disease ${ }^{(220)}$.

\section{Clinical indications and health promotion}

Vit-D insufficiency as currently determined is suggested in approximately $14 \%$ of the world's population ${ }^{(221)}$. This has resulted to public vit-D recommendations from Government institutions and agencies between 25 and $250 \mu \mathrm{g} / \mathrm{d}^{(29-31)}$. In response to public health promotion of vit-D deficiency to resolve what has now been classed as a "major global

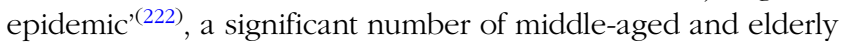
individuals are supplementing their vit-D intake in an attempt to reduce the putative health risks associated with vit-D deficiency, including cognitive decline and osteoporosis ${ }^{(223)}$.

It is estimated that $86 \%$ of the global population is reporting as having sufficient vit-D levels ${ }^{(221)}$. By extension, it is possible that recommendation for exogenous intake through fortified foods/supplements at 15 to $20 \mu \mathrm{g}$ may be potentially harmful in some individuals, particularly if endogenous levels of $1,25(\mathrm{OH})_{2} \mathrm{D}_{3}$ are already heightened ${ }^{(223)}$. Researchers in the USA analysed data from a national survey over 15 years (1999-2014) and found an 18\% increase in the people taking vit-D over $25 \mu \mathrm{g} / \mathrm{d}$ and a $2 \cdot 8 \%$ increase in the amount of people taking of over $100 \mu \mathrm{g}$ of vit-D/d $\mathrm{d}^{(223)}$. Unfortunately, this trend is not isolated and can be seen on a global scale. In Australia, the majority ( $77 \%$ ) of Australian citizens have supposedly sufficient vit-D levels, yet remarkably, one in twenty adults were reported to be taking vit-D supplements. Among those with high serum vit-D $((25(\mathrm{OH}) \mathrm{D})>100 \mathrm{nmol} / \mathrm{l})$, one in ten reported regular intake of exogenous vit- $\mathrm{D}^{(224)}$. Similarly, despite more than two-thirds (68\%) of Canadians reported having sufficient vit-D serum levels $((25(\mathrm{OH}) \mathrm{D}) ;>50 \mathrm{nmol} / \mathrm{l}), 34 \%$ still report taking 
a regular vit-D supplements ${ }^{(225)}$. Furthermore, several large national and international clinical trials have confirmed participant numbers between 5000 and 30000 per trial for a variety of indications. These trials are currently administering from $50 \mu \mathrm{g}$ vit-D/ $\mathrm{d}^{(226)}$ or $1500-2500 \mu \mathrm{g}$ vit-D/month ${ }^{(227,228)}$, exploring therapeutic rates of $250-7500 \mu \mathrm{g}$ vit-D/dose $\mathrm{e}^{(28,229-233)}$ without adequate evidence such levels are safe in the context of cognitive function. Clearly, serum measures of vit-D must be considered carefully as a putative surrogate marker of CNS vit-D homeostasis

\section{Conclusion}

There is substantial scientific, clinical and public health interest in how vit-D modulates CNS function. On the basis of purported benefits in cognitive performance, supplementary use of vit-D has increased markedly in developed countries, often without clinical indication. The latter may be of some concern given an emerging body of evidence which suggests either no benefit or possibly even harm in subjects taking exogenous vit-D supplementation who have otherwise adequate levels of vit-D as currently assessed. Significant limitations in our contemporary understanding of vit-D effects on the CNS include the relevance of serum measures to CNS homeostasis, regulation of conversion and deactivation of bioactive metabolites with studies suggesting significant subject variability. Other challenges include understanding longitudinal/life-long and possibly epigenetic effects when considering causal association realised over decades of life. Greater insight into fundamental physiological processes realised through robust pre-clinical models would be informative in supporting clinical conisiderations of vit-D homeostasis in the context of CNS health.

\section{Acknowledgements}

This work was supported by the National Health and Medical Research Council of Australia.

All authors contributed to the literature search, manuscript design, manuscript writing and revisions of the manuscript. All authors read and approved the final manuscript.

The authors declare no conflicts of interest.

\section{References}

1. Moreno MA, Furtner F \& Rivara FP (2012) Vitamin D and bone health. Arch Pediatr Adolesc Med 166, 684.

2. Sugiyama T \& Oda H (2016) Vitamin D status and bone health in obesity: another mechanistic point of view. Am J Clin Nutr 104, 1487.

3. Francis RM, Aspray TJ, Bowring CE, et al. (2015) National osteoporosis society practical clinical guideline on vitamin $\mathrm{D}$ and bone health. Maturitas 80, 119-121.

4. Aspray TJ, Bowring C, Fraser W, et al. (2014) National osteoporosis society vitamin D guideline summary. Age Ageing 43, 592-595.

5. Mohr SB (2009) A brief history of vitamin D and cancer prevention. Ann Epidemiol 19, 79-83.
6. Anastasiou CA, Yannakoulia M \& Scarmeas N (2014) Vitamin $\mathrm{D}$ and cognition: an update of the current evidence. $J$ Alzheimers Dis 42, Suppl. 3, S71-S80.

7. Groves NJ, McGrath JJ \& Burne TH (2014) Vitamin D as a neurosteroid affecting the developing and adult brain. Annu Rev Nutr 34, 117-141.

8. Garcion E, Wion-Barbot N, Montero-Menei CN, et al. (2002) New clues about vitamin D functions in the nervous system. Trends Endocrinol Metab 13, 100-105.

9. Cui X, Gooch H, Groves NJ, et al. (2015) Vitamin D and the brain: key questions for future research. I Steroid Biochem Mol Biol 148, 305-309.

10. Kalueff AV, Eremin KO \& Tuohimaa P (2004) Mechanisms of neuroprotective action of vitamin $\mathrm{D}(3)$. Biochemistry (Mosc) 69, 738-741.

11. Manson JE, Brannon PM, Rosen CJ, et al. (2016) Vitamin D deficiency - is there really a pandemic? N Engl J Med 375, $1817-1820$

12. Peterlik M (2012) Vitamin D insufficiency and chronic diseases: hype and reality. Food Funct 3, 784-794.

13. Afzal S, Bojesen SE \& Nordestgaard BG (2014) Reduced 25-hydroxyvitamin D and risk of Alzheimer's disease and vascular dementia. Alzheimers Dement 10, 296-302.

14. Annweiler C, Dursun E, Féron F, et al. (2015) 'Vitamin D and cognition in older adults': updated international recommendations. J Intern Med 277, 45-57.

15. Zhao B, Zhang W, Du S, et al. (2016) Vitamin D receptor BsmI polymorphism and osteoporosis risk in post-menopausal women. Arch Med Sci 12, 25-30.

16. Brondum-Jacobsen $\mathrm{P}$, Nordestgaard BG, Schnohr P, et al. (2013) 25-Hydroxyvitamin D and symptomatic ischemic stroke: an original study and meta-analysis. Ann Neurol 73, 38-47.

17. Annweiler C, Montero-Odasso M, Hachinski V, et al. (2013) Vitamin D concentration and lateral cerebral ventricle volume in older adults. Mol Nutr Food Res 57, 267-276.

18. Milovanović Olivera Z (2017) Vitamin D deficiency and its importance - a global problem of today, realistic or not? Serbian J Exp Clin Res 18, 3-12.

19. Annweiler C, Llewellyn DJ \& Beauchet O (2013) Low serum vitamin D concentrations in Alzheimer's disease: a systematic review and meta-analysis. J Alzheimers Dis 33, 659-674.

20. Littlejohns TJ, Henley WE, Lang IA, et al. (2014) Vitamin D and the risk of dementia and Alzheimer disease. Neurology 83, 920-928.

21. Llewellyn DJ, Lang IA, Langa KM, et al. (2010) Vitamin D and risk of cognitive decline in elderly persons. Arch Intern Med 170, 1135-1141.

22. Slinin Y, Paudel M, Taylor BC, et al. (2012) Association between serum $25(\mathrm{OH})$ vitamin $\mathrm{D}$ and the risk of cognitive decline in older women. J Gerontol A Biol Sci Med Sci 67, 1092-1098.

23. Slinin Y, Paudel ML, Taylor BC, et al. (2010) 25Hydroxyvitamin D levels and cognitive performance and decline in elderly men. Neurology 74, 33-41.

24. Lam V, Takechi R, Pallabage-Gamarallage M, et al. (2015) The Vitamin D, ionised calcium and parathyroid hormone axis of cerebral capillary function: therapeutic considerations for vascular-based neurodegenerative disorders (Vitamin D Modulation of Cerebral Capillary Function). PLOS ONE 10, e0125504.

25. Granic A, Hill TR, Kirkwood TB, et al. (2015) Serum 25hydroxyvitamin $\mathrm{D}$ and cognitive decline in the very old: the Newcastle 85+ Study. Eur J Neurol 22, 106-115, e106-107.

26. Tsujikawa H, Kurotaki Y, Fujimori T, et al. (2003) Klotho, a gene related to a syndrome resembling human premature 
aging, functions in a negative regulatory circuit of vitamin D endocrine system. Mol Endocrinol 17, 2393-2403.

27. Razzaque MS \& Lanske B (2006) Hypervitaminosis D and premature aging: lessons learned from Fgf23 and Klotho mutant mice. Trends Mol Med 12, 298-305.

28. Wu F, Staykova T, Horne A, et al. (2003) Efficacy of an oral, 10-day course of high-dose calciferol in correcting vitamin D deficiency. $N Z$ Med J 116, U536.

29. Vitamin D Council (2017) How do I get the vitamin D my body needs? https://www.vitamindcouncil.org/about-vitamin-d/howdo-i-get-the-vitamin-d-my-body-needs/ (accessed June 2017).

30. Endocrine Society (2019) Clinical practice guidelines of the endocrine society. https://www.endocrine.org/education-andpractice-management/clinical-practice-guidelines (accessed June 2017).

31. Osteoporosis-Australia (2014) Vitamin D. http://www.osteo porosis.org.au/vitamin-d (accessed June 2017).

32. Przybelski R, Agrawal S, Krueger D, et al. (2008) Rapid correction of low vitamin D status in nursing home residents. Osteoporos Int 19, 1621-1628.

33. Cavalier E, Wallace A, Knox S, et al. (2008) Serum vitamin D measurement may not reflect what you give to your patients. J Bone Mineral Res 23, 1864-1864.

34. Sintzel M, Rametta M \& Reder A (2017) Vitamin D and multiple sclerosis: a comprehensive review. Neurol Ther 7, 59-85.

35. Veldurthy V, Wei R, Oz L, et al. (2016) Vitamin D, calcium homeostasis and aging. Bone Res $\mathbf{4}, 16041$.

36. Lehmann B \& Meurer M (2010) Vitamin D metabolism. Dermatol Ther 23, 2-12.

37. Holick MF (2007) Vitamin D deficiency. $N$ Engl J Med 357, 266-281.

38. Diesel B, Seifert M, Radermacher J, et al. (2004) Towards a complete picture of splice variants of the gene for 25hydroxyvitamin D31alpha-hydroxylase in brain and skin cancer. I Steroid Biochem Mol Biol 89-90, 527-532.

39. Henry HL (2011) Regulation of vitamin D metabolism. Best Pract Res Clin Endocrinol Metab 25, 531-541.

40. Jones G, Prosser DE \& Kaufmann M (2014) Cytochrome P450-mediated metabolism of vitamin D. J Lipid Res 55, $13-31$.

41. Sitara D (2007) Correlation among hyperphosphatemia, type II sodium phosphate transporter activity, and vitamin D metabolism in Fgf-23 null mice. Ann New York Acad Sci 1116, 485

42. Gil Á, Plaza-Diaz J \& Mesa MD (2018) Vitamin D: classic and novel actions. Ann Nutr Metab 72, 87.

43. Veldurthy V, Wei R, Campbell M, et al. (2016) 25-Hydroxyvitamin $\mathrm{D}_{3}$ 24-hydroxylase: a key regulator of $1,25(\mathrm{OH})_{2} \mathrm{D}_{3}$ catabolism and calcium homeostasis. Vitam Horm 100, 137

44. Bikle DD (2014) Vitamin D metabolism, mechanism of action, and clinical applications. Chem Biol 21, 319-329.

45. Ferrari SL, Bonjour JP \& Rizzoli R (2005) Fibroblast growth factor-23 relationship to dietary phosphate and renal phosphate handling in healthy young men. I Clin Endocrinol Metab 90, 1519-1524.

46. Antoniucci DM, Yamashita T \& Portale AA (2006) Dietary phosphorus regulates serum fibroblast growth factor-23 concentrations in healthy men. J Clin Endocrinol Metab 91, $3144-3149$

47. Urakawa I, Yamazaki Y, Shimada T, et al. (2006) Klotho converts canonical FGF receptor into a specific receptor for FGF23. Nature 444, 770-774.

48. Prié D \& Friedlander G (2010) Reciprocal control of 1,25-dihydroxyvitamin D and FGF23 formation involving the FGF23/Klotho system. Clin J Am Soc Nephrol 5, 1717.
49. Stumpf WE \& O'Brien LP (1987) $1,25(\mathrm{OH})_{2}$ vitamin $\mathrm{D}_{3}$ sites of action in the brain. An autoradiographic study. Histochemistry 87, 393-406.

50. Lee D-H, Kim JH, Jung MH, et al. (2019) Total 25-hydroxy vitamin D level in cerebrospinal fluid correlates with serum total, bioavailable, and free 25-hydroxy vitamin D levels in Korean population. PLOS ONE 14, e0213389-e0213389.

51. Ciesielski F, Sato Y, Chebaro Y, et al. (2012) Structural basis for the accommodation of bis- and tris-aromatic derivatives in vitamin D nuclear receptor. J Med Chem 55, 8440.

52. Kato S (2000) The function of vitamin D receptor in vitamin D action. J Biochem 127, 717-722.

53. Zittermann A \& Gummert JF (2010) Nonclassical vitamin D action. Nutrients $\mathbf{2}, 408-425$.

54. Klopot A, Hance KW, Peleg S, et al. (2007) Nucleo-cytoplasmic cycling of the vitamin $\mathrm{D}$ receptor in the enterocyte-like cell line, Caco-2. J Cell Biochem 100, 617-628.

55. Gezen-Ak D (2017) Vitamin D receptor is present on the neuronal plasma membrane and is co-localized with amyloid precursor protein, ADAM10 or Nicastrin. PLOS ONE 12, e0188605.

56. Litwack G (2016) Vitamin D hormone / edited by Gerald Litwack ; contributors Jungmi Abn [and fifty two others], 1st ed. Amsterdam, The Netherlands: Academic Press.

57. Pike JW \& Meyer MB (2014) Fundamentals of vitamin D hormone-regulated gene expression. J Steroid Biochem Mol Biol 144, 5-11.

58. Pike JW, Meyer MB \& Bishop KA (2012) Regulation of target gene expression by the vitamin $\mathrm{D}$ receptor - an update on mechanisms. Rev Endocr Metab Disord 13, 45-55.

59. Mangelsdorf DJ \& Evans RM (1995) The RXR heterodimers and orphan receptors. Cell $\mathbf{8 3}, 841-850$.

60. Veenstra TD, Johnson KL, Tomlinson AJ, et al. (1998) Zincinduced conformational changes in the DNA-binding domain of the vitamin $\mathrm{D}$ receptor determined by electrospray ionization mass spectrometry. J Am Soc Mass Spectrom 9, 8-14.

61. Prufer K, Veenstra TD, Jirikowski GF, et al. (1999) Distribution of 1,25-dihydroxyvitamin $\mathrm{D}_{3}$ receptor immunoreactivity in the rat brain and spinal cord. $J$ Chem Neuroanat 16, 135-145.

62. Eyles DW, Liu PY, Josh P, et al. (2014) Intracellular distribution of the vitamin D receptor in the brain: comparison with classic target tissues and redistribution with development. Neuroscience 268, 1-9.

63. Toptas B, Kafadar AM, Cacina C, et al. (2013) The vitamin D receptor (VDR) gene polymorphisms in Turkish brain cancer patients. Biomed Res Int 2013, 295791.

64. Gezen-Ak D, Alaylioglu M, Genc G, et al. (2017) GC and VDR SNPs and vitamin D Levels in parkinson's disease: the relevance to clinical features. Neuromol Med 19, 24-40.

65. Cui X, Pelekanos M, Liu PY, et al. (2013) The vitamin D receptor in dopamine neurons; its presence in human substantia nigra and its ontogenesis in rat midbrain. Neuroscience 236, $77-87$.

66. Wang Y, Becklund BR \& DeLuca HF (2010) Identification of a highly specific and versatile vitamin D receptor antibody. Arch Biochem Biophys 494, 166-177.

67. Wang Y \& DeLuca HF (2011) Is the vitamin D receptor found in muscle? Endocrinology 152, 354-363.

68. Wang Y, Zhu J \& Deluca HF (2012) Where is the vitamin D receptor? Arch. Biochem Biophys 523, 123-133.

69. Boyan BD, Chen J \& Schwartz Z (2012) Mechanism of Pdia3-dependent 1alpha,25-dihydroxy vitamin $\mathrm{D}_{3}$ signaling in musculoskeletal cells. Steroids 77, 892-896.

70. Eyles DW, Smith S, Kinobe R, et al. (2005) Distribution of the vitamin $\mathrm{D}$ receptor and 1 alpha-hydroxylase in human brain. J Chem Neuroanat 29, 21-30. 
71. Eyles D, Brown J, Mackay-Sim A, et al. (2003) Vitamin $\mathrm{D}_{3}$ and brain development. Neuroscience 118, 641-653.

72. Landel V, Annweiler C, Millet P, et al. (2016) Vitamin D, cognition and Alzheimer's disease: the therapeutic benefit is in the D-tails. J Alzheimers Dis 53, 419-444.

73. Smolders J, Schuurman KG, van Strien ME, et al. (2013) Expression of vitamin D receptor and metabolizing enzymes in multiple sclerosis-affected brain tissue. J Neuropathol Exp Neurol 72, 91-105.

74. El-Atifi M, Dreyfus M, Berger F, et al. (2015) Expression of CYP2R1 and VDR in human brain pericytes: the neurovascular vitamin D autocrine/paracrine model. Neuroreport 26, 245-248.

75. Landel V, Stephan D, Cui X, et al. (2018) Differential expression of vitamin D-associated enzymes and receptors in brain cell subtypes. J Steroid Biochem Mol Biol 177, 129-134.

76. Xue Y, He X, Li HD, et al. (2015) Simultaneous quantification of 25-hydroxyvitamin $\mathrm{D}_{3}$ and 24,25-dihydroxyvitamin $\mathrm{D}_{3}$ in rats shows strong correlations between serum and brain tissue levels. Int J Endocrinol 2015, 296531.

77. Razzaque MS (2018) Can adverse effects of excessive vitamin D supplementation occur without developing hypervitaminosis D? J Ster Biochem Mol Biol 180, 81-86.

78. Annweiler C, Allali G, Allain P, et al. (2009) Vitamin D and cognitive performance in adults: a systematic review. EurJ Neurol 16, 1083-1089.

79. Wilkins C, Sheline Y, Roe C, et al. (2006) Vitamin D deficiency is associated with low mood and worse cognitive performance in older adults. Am J Geriatr Psych 14, 1032-1040.

80. Przybelski RJ \& Binkley NC (2007) Is vitamin D important for preserving cognition? A positive correlation of serum 25-hydroxyvitamin D concentration with cognitive function. Arch Biochem Biophys 460, 202-205.

81. McGrath J, Scragg R, Chant D, et al. (2007) No association between serum 25-hydroxyvitamin $\mathrm{D}_{3}$ level and performance on psychometric tests in NHANES III. Neuroepidemiology 29, 49-54.

82. Maddock J, Geoffroy MC, Power C, et al. (2014) 25-Hydroxyvitamin D and cognitive performance in mid-life. Br J Nutr 111, 904-914.

83. Castle M, Fiedler N, Pop LC, et al. (2019) Three doses of vitamin $\mathrm{D}$ and cognitive outcomes in older women: a doubleblind randomized controlled trial. J Gerontol A Biol Sci Med Sci (epublication ahead of print version 14 February 2019).

84. Maddock J, Cavadino A, Power C, et al. (2015) 25Hydroxyvitamin D, APOE varepsilon4 genotype and cognitive function: findings from the 1958 British birth cohort. Eur JClin Nutr 69, 505-508.

85. Holick MF (2015) Vitamin D and brain health: the need for vitamin D supplementation and sensible sun exposure. J Internal Med 277, 90-93.

86. Karakis I, Pase MP, Beiser A, et al. (2016) Association of serum vitamin $D$ with the risk of incident dementia and subclinical indices of brain aging: the framingham heart study. J Alzheimers Dis 51, 451-461.

87. Hooshmand B, Lökk J, Solomon A, et al. (2014) Vitamin D in relation to cognitive impairment, cerebrospinal fluid biomarkers, and brain volumes. J Gerontol Series A: Biomed Sci Med Sci 69, 1132-1138.

88. Chaves SK, Feitosa CM \& da S Araújo L (2016) Alkaloids pharmacological activities - prospects for the development of phytopharmaceuticals for neurodegenerative diseases. Curr Pharm Biotechnol 17, 629-635.

89. Schneider AL, Lutsey PL, Alonso A, et al. (2014) Vitamin D and cognitive function and dementia risk in a biracial cohort: the ARIC Brain MRI Study. Eur J Neurol 21, 1211-1218, e1269-e1270.
90. Schneider ALC, Zhao D, Lutsey PL, et al. (2018) Serum vitamin D concentrations and cognitive change over 20 years: the Atherosclerosis Risk in Communities Neurocognitive Study. Neuroepidemiology 51, 131-137.

91. Graf CE, Rossi C, Giannelli SV, et al. (2014) Vitamin D is not associated with cognitive status in a cohort of very old hospitalized patients. J Alzheimers Dis 42, Suppl 3, S53-S61.

92. Rossom RC, Espeland MA, Manson JE, et al. (2012) Calcium and vitamin D supplementation and cognitive impairment in the Women's Health Initiative. J Am Geriatr Soc 60 , 2197-2205.

93. Dean AJ, Bellgrove MA, Hall T, et al. (2011) Effects of vitamin D supplementation on cognitive and emotional functioning in young adults - a randomised controlled trial (Can Vitamin D Improve Cognitive Function?). PLOS ONE 6, e25966.

94. Maddock J, Zhou A, Cavadino A, et al. (2017) Vitamin D and cognitive function: a Mendelian randomisation study. Sci Rep 7, 13230-13230.

95. Overman MJ, Pendleton N, O'Neill TW, et al. (2017) Evaluation of cognitive subdomains, 25-hydroxyvitamin D, and 1,25-dihydroxyvitamin D in the European male ageing study. Eur J Nutr 56, 2093-2103.

96. Manders M, Groot L, Hoefnagels W, et al. (2009) The effect of a nutrient dense drink on mental and physical function in institutionalized elderly people. J Nutr Health Aging 13, 760-767.

97. Stein MS, Scherer SC, Ladd KS, et al. (2011) A randomized controlled trial of high-dose vitamin $\mathrm{D}_{2}$ followed by intranasal insulin in Alzheimer's disease. J Alzheimers Dis 26, 477-484.

98. Bartali B, Devore E, Grodstein F, et al. (2014) Plasma vitamin D levels and cognitive function in aging women: the nurses' health study. J Nutr Health Aging 18, 400-406.

99. Jackson RD, Lacroix AZ, Cauley JA, et al. (2003) The Women's Health Initiative Calcium-Vitamin D trial: overview and baseline characteristics of participants. Ann Epidemiol 13, S98-S106.

100. Lam V, Albrecht M, Takechi R, et al. (2015) Serum 25-hydroxyvitamin $\mathrm{D}$ is associated with reduced verbal episodic memory in healthy, middle-aged and older adults. Eur $J$ Nutr 55, 1503-1513.

101. Brown J, Bianco JI, McGrath JJ, et al. (2003) 1,25-Dihydroxyvitamin $\mathrm{D}_{3}$ induces nerve growth factor, promotes neurite outgrowth and inhibits mitosis in embryonic rat hippocampal neurons. Neurosci Lett 343, 139-143.

102. Flanagan L, Packman K, Juba B, et al. (2003) Efficacy of Vitamin D compounds to modulate estrogen receptor negative breast cancer growth and invasion. $J$ Steroid Biochem Mol Biol 84, 181-192.

103. Kasiappan R, Sun Y, Lungchukiet P, et al. (2014) Vitamin D suppresses leptin stimulation of cancer growth through microRNA. Cancer Res 74, 6194.

104. Chen P-T, Hsieh C-C, Wu C-T, et al. (2015) $1 \alpha, 25-$ Dihydroxyvitamin $\mathrm{D}_{3}$ inhibits esophageal squamous cell carcinoma progression by reducing IL6 signaling. Mol Cancer Therapeut 14, 1365.

105. Huebbe P, Nebel A, Siegert S, et al. (2011) APOE $€ 4$ is associated with higher vitamin D levels in targeted replacement mice and humans. FASEB J 25, 3262.

106. Clipp SL, Burke A, Hoffman-Bolton J, et al. (2011) Sun-seeking behavior to increase cutaneous vitamin D synthesis: when prevention messages conflict. Publ Health Rep. 126, 533-539.

107. Borradale D \& Kimlin M (2009) Vitamin D in health and disease: an insight into traditional functions and new roles for the 'sunshine vitamin'. Nutr Res Rev 22, 118-136.

108. Diehl JW \& Chiu MW (2010) Effects of ambient sunlight and photoprotection on vitamin D status. Dermatol Ther 23, 48-60. 
109. Youl PH, Janda M \& Kimlin M (2009) Vitamin D and sun protection: the impact of mixed public health messages in Australia. Int J Cancer 124, 1963-1970.

110. Gallagher JC (2013) Vitamin D and aging. Endocrinol Metab Clin North Am 42, 319-332.

111. Eastell R, Yergey AL, Vieira NE, et al. (1991) Interrelationship among vitamin D metabolism, true calcium absorption, parathyroid function, and age in women: evidence of an age-related intestinal resistance to 1,25-dihydroxyvitamin D action. J Bone Miner Res 6, 125-132.

112. Ebeling P, Yergey A, Vieira N, et al. (1994) Influence of age on effects of endogenous 1,25-dihydroxyvitamin D on calcium absorption in normal women. Calcified Tissue Int $\mathbf{5 5}$ 330-334.

113. Ebeling PR, Sandgren ME, DiMagno EP, et al. (1992) Evidence of an age-related decrease in intestinal responsiveness to vitamin D: relationship between serum 1,25-dihydroxyvitamin $\mathrm{D}_{3}$ and intestinal vitamin $\mathrm{D}$ receptor concentrations in normal women. J Clin Endocrinol Metab 75, 176-182.

114. Horst RL, Goff JP \& Reinhardt TA (1990) Advancing age results in reduction of intestinal and bone 1,25-dihydroxyvitamin D receptor. Endocrinology 126, 1053-1057.

115. Kinyamu HK, Gallagher JC, Prahl JM, et al. (1997) Association between intestinal vitamin $\mathrm{D}$ receptor, calcium absorption, and serum 1,25 dihydroxyvitamin D in normal young and elderly women. J Bone Miner Res 12, 922-928.

116. Wood RJ, Fleet JC, Cashman K, et al. (1998) Intestinal calcium absorption in the aged rat: evidence of intestinal resistance to 1,25(OH)2 vitamin D. Endocrinology 139, 3843-3848.

117. Huang CH, Huang YA, Lai YC, et al. (2017) Prevalence and predictors of hypovitaminosis D among the elderly in subtropical region. PLOS ONE 12, e0181063.

118. Rajakumar K, Greenspan SL, Thomas SB, et al. (2007) SOLAR ultraviolet radiation and vitamin D: a historical perspective. Am J Publ Health 97, 1746.

119. Razzaque MS (2009) The FGF23-Klotho axis: endocrine regulation of phosphate homeostasis. Nat Rev Endocrinol 5, 611.

120. Chen T-H, Kuro-O M, Chen C-H, et al. (2013) The secreted Klotho protein restores phosphate retention and suppresses accelerated aging in Klotho mutant mice. Eur J Pharmacol 698, 67-73.

121. Arking ED, Atzmon CG, Arking CA, et al. (2005) Association between a functional variant of the KLOTHO gene and high-density lipoprotein cholesterol, blood pressure, stroke, and longevity. Circ Res 96, 412-418.

122. Pettersen JA, Fok AC \& Robin Hsiung G-Y (2015) Fok1 vitamin D receptor gene polymorphisms and association with cognition. Alzheimer's \& Dementia: J Alzheimer's Assoc 11, P358-P358.

123. Kuningas M, Mooijaart SP, Jolles J, et al. (2009) VDR gene variants associate with cognitive function and depressive symptoms in old age. Neurobiol Aging 30, 466-473.

124. Monticielo OA, Brenol JCT, Chies JAB, et al. (2012) The role of Bsm I and Fok I vitamin D receptor gene polymorphisms and serum 25-hydroxyvitamin D in Brazilian patients with systemic lupus erythematosus. Lupus 21, 43-52.

125. Vilarino FL, Bianco B, Lerner TG, et al. (2011) Analysis of vitamin $\mathrm{D}$ receptor gene polymorphisms in women with and without endometriosis. Hum Immunol 72, 359-363.

126. Uitterlinden AG, Fang Y, van Meurs JBJ, et al. (2004) Genetics and biology of vitamin D receptor polymorphisms. Gene 338, 143-156.

127. Lehmann DJ, Refsum H, Warden DR, et al. (2011) The vitamin $\mathrm{D}$ receptor gene is associated with Alzheimer's disease. Neurosci Lett 504, 79-82.
128. Keyimu K, Zhou X, Miao H, et al. (2014) Relationship between vitamin $\mathrm{D}$ receptor gene polymorphism and mild cognitive impairment in elderly Uygur people. Int J Clin Exp Med 7, 5282-5288.

129. Niu M, Wang L \& Xie A (2015) ApaI, BsmI, eFokI, and TaqI polymorphisms in the vitamin $\mathrm{D}$ receptor Gene and Parkinson's Disease. Chin Med J 128, 1809-1814.

130. Beydoun MA, Tajuddin SM, Dore GA, et al. (2017) Vitamin D receptor and megalin gene polymorphisms are associated with longitudinal cognitive change among African-American urban adults. J Nutr 147, 1048-1062, jn244962.

131. Beydoun MA, Ding EL, Beydoun HA, et al. (2012) Vitamin D receptor and megalin gene polymorphisms and their associations with longitudinal cognitive change in US adults. $\mathrm{Am} \mathrm{J}$ Clin Nutr 95, 163

132. Buell JS \& Dawson-Hughes B (2008) Vitamin D and neurocognitive dysfunction: preventing 'D'ecline? Mol Aspects Med 29, 415-422.

133. Wang L-L, Pan X-L, Wang Y, et al. (2011) A single nucleotide polymorphism in LRP2 is associated with susceptibility to Alzheimer's disease in the Chinese population. Clin Chim Acta 412, 268-270.

134. Gatto NM, Sinsheimer JS, Cockburn M, et al. (2015) Vitamin D receptor gene polymorphisms and Parkinson's disease in a population with high ultraviolet radiation exposure. J Neurol Sci 352, 88-93.

135. Bornman L (2013) Vitamin D receptor gene expression and function in a South African population: ethnicity, vitamin D and FOKI. PLOS ONE 8, e67663.

136. McGrath JJ, Saha S, Burne THJ, et al. (2010) A systematic review of the association between common single nucleotide polymorphisms and 25-hydroxyvitamin D concentrations. J Steroid Biochem Mol Biol 121, 471-477.

137. Gatto NM, Paul KC, Sinsheimer JS, et al. (2016) Vitamin D receptor gene polymorphisms and cognitive decline in Parkinson's disease. J Neurol Sci 370, 100-106.

138. Wilkinson RJ, Llewelyn M, Toossi Z, et al. (2000) Influence of vitamin D deficiency and vitamin D receptor polymorphisms on tuberculosis among Gujarati Asians in west London: a case-control study. Lancet 355, 618-621.

139. Wong HL, Seow A, Arakawa K, et al. (2003) Vitamin D receptor start codon polymorphism and colorectal cancer risk: effect modification by dietary calcium and fat in Singapore Chinese. Carcinogenesis 24, 1091-1095.

140. Abrams SA, Griffin IJ, Hawthorne KM, et al. (2005) Vitamin D receptor Fok1 polymorphisms affect calcium absorption, kinetics, and bone mineralization rates during puberty. J Bone Miner Res 20, 945-953.

141. Miyamoto K, Kesterson RA, Yamamoto H, et al. (1997) Structural organization of the human vitamin D receptor chromosomal gene and its promoter. Mol Endocrinol 11, $1165-1179$.

142. Arai H, Miyamoto K, Taketani Y, et al. (1997) A vitamin D receptor gene polymorphism in the translation initiation codon: effect on protein activity and relation to bone mineral density in Japanese women. J Bone Miner Res 12, 915-921.

143. Orton SM, Morris AP, Herrera BM, et al. (2008) Evidence for genetic regulation of vitamin D status in twins with multiple sclerosis. Am J Clin Nutr 88, 441-447.

144. van de Haar H, Burg-Mans S, Jansen J, et al. (2017) Bloodbrain barrier leakage in patients with early Alzheimer disease. Radiology 282, 615-615.

145. Hawkins BT \& Davis TP (2005) The blood-brain barrier/ neurovascular unit in health and disease. Pharmacol Rev 57, 173-185. 
146. Won S, Sayeed I, Peterson BL, et al. (2015) Vitamin D prevents hypoxia/reoxygenation-induced blood-brain barrier disruption via vitamin $\mathrm{D}$ receptor-mediated NF-kB signaling pathways. PLOS ONE 10, e 0122821.

147. Sandoval KE \& Witt KA (2008) Blood-brain barrier tight junction permeability and ischemic stroke. Neurobiol Dis 32, 200-219.

148. Janelidze S, Hertze J, Nägga K, et al. (2017) Increased bloodbrain barrier permeability is associated with dementia and diabetes but not amyloid pathology or APOE genotype. Neurobiol Aging 51, 104-112.

149. Gorelick BP, Scuteri EA, Black MS, et al. (2011) Vascular contributions to cognitive impairment and dementia: a statement for healthcare professionals from the American Heart Association/American Stroke Association. Stroke 42, 2672-2713.

150. Takechi R, Pallebage-Gamarallage MM, Lam V, et al. (2014) Long-term probucol therapy continues to suppress markers of neurovascular inflammation in a dietary induced model of cerebral capillary dysfunction. Lipids Health Dis. 13, 91 .

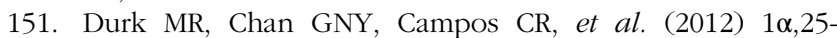
Dihydroxyvitamin $\mathrm{D}_{3}$-liganded vitamin $\mathrm{D}$ receptor increases expression and transport activity of P-glycoprotein in isolated rat brain capillaries and human and rat brain microvessel endothelial cells. $J$ Neurochem 123, 944-953.

152. Cannon RE, Peart JC, Hawkins BT, et al. (2012) Targeting blood-brain barrier sphingolipid signaling reduces basal P-glycoprotein activity and improves drug delivery to the brain. Proc Natl Acad Sci US A 109, 15930.

153. Ghaly S, Kaakoush NO, Lloyd F, et al. (2018) Ultraviolet irradiation of skin alters the faecal microbiome independently of vitamin D in mice. Nutrients 10, E1069.

154. Krementsov DN, Asarian L, Fang Q, et al. (2018) Sex-specific gene-by-vitamin $\mathrm{D}$ interactions regulate susceptibility to central nervous system autoimmunity. Front Immunol 9, 1622.

155. Briones TL \& Darwish H (2012) Vitamin D mitigates age-related cognitive decline through the modulation of pro-inflammatory state and decrease in amyloid burden. J Neuroinflammation $\mathbf{9}, 244$.

156. Garcion E, Nataf S, Berod A, et al. (1997) 1,25Dihydroxyvitamin $\mathrm{D}_{3}$ inhibits the expression of inducible nitric oxide synthase in rat central nervous system during experimental allergic encephalomyelitis. Brain Res Mol Brain Res 45, 255-267.

157. Lu'o'ng KV \& Nguyen LT (2013) The role of vitamin D in Alzheimer's disease: possible genetic and cell signaling mechanisms. Am J Alzheimers Dis Other Demen 28, 126-136.

158. Ogura M, Nakamichi N, Takano K, et al. (2006) Functional expression of A glutamine transporter responsive to downregulation by lipopolysaccharide through reduced promoter activity in cultured rat neocortical astrocytes. J Neurosci Res 83, $1447-1460$.

159. Taniura H, Ito M, Sanada N, et al. (2006) Chronic vitamin $D_{3}$ treatment protects against neurotoxicity by glutamate in association with upregulation of vitamin D receptor mRNA expression in cultured rat cortical neurons. J Neurosci Res 83, 1179-1189.

160. Binkley N, Dawson-Hughes B, Durazo-Arvizu R, et al. (2017) Vitamin D measurement standardization: the way out of the chaos. J Steroid Biochem Mol Biol 173, 117-121.

161. Institute of Medicine of the National Academies (2011) Overview of vitamin D. In Dietary Reference Intakes for Calcium and Vitamin D, p. 3 [AC Ross, CL Taylor, AL Yaktine and HB Del Valle, editors]. Washington, DC: The National Academies Press.
162. Holick MF, Binkley NC, Bischoff-Ferrari HA, et al. (2011) Evaluation, treatment, and prevention of vitamin D deficiency: an Endocrine Society clinical practice guideline. J Clin Endocrinol Metab 96, 1911-1930.

163. Pludowski P, Holick MF, Grant WB, et al. (2017) Vitamin D supplementation guidelines. I Steroid Biochem Mol Biol. 175, 125-135.

164. Garland CF, Kim JJ, Mohr SB, et al. (2014) Meta-analysis of all-cause mortality according to serum 25-hydroxyvitamin D. Am J Public Health 104, e43-e50.

165. Pludowski P, Holick MF, Pilz S, et al. (2013) Vitamin D effects on musculoskeletal health, immunity, autoimmunity, cardiovascular disease, cancer, fertility, pregnancy, dementia and mortality-a review of recent evidence. Autoimmun Rev 12, 976-989.

166. Wimalawansa SJ (2018) Non-musculoskeletal benefits of vitamin D. J Steroid Biochem Mol Biol 175, 60-81.

167. Ross AC, Manson JE, Abrams SA, et al. (2011) The 2011 report on dietary reference intakes for calcium and vitamin D from the Institute of Medicine: what clinicians need to know. $J$ Clin Endocrinol Metab 96, 53-58.

168. Lai JC, Bikle DD, Lizaola B, et al. (2015) Total $25(\mathrm{OH})$ vitamin $\mathrm{D}$, free $25(\mathrm{OH})$ vitamin $\mathrm{D}$ and markers of bone turnover in cirrhotics with and without synthetic dysfunction. Liver Int 35, 2294-2300.

169. Hilger J, Friedel A, Herr R, et al. (2014) A systematic review of vitamin D status in populations worldwide. Br J Nutr $\mathbf{1 1 1}$, 23-45.

170. Reid D, Toole BJ, Knox S, et al. (2011) The relation between acute changes in the systemic inflammatory response and plasma 25-hydroxyvitamin D concentrations after elective knee arthroplasty. Am J Clin Nutr 93, 1006.

171. Snellman G, Melhus H, Gedeborg R, et al. (2010) Determining vitamin D status: a comparison between commercially available assays. PLOS ONE 5, e11555.

172. Zahedi Rad M, Neyestani T, Nikooyeh B, et al. (2015) Competitive protein-binding assay-based enzyme-immunoassay method, compared to high-pressure liquid chromatography, has a very lower diagnostic value to detect vitamin D deficiency in 9-12 years children. Int J Prev Med 6, 67.

173. Binkley SN, Krueger ED, Cowgill FC, et al. (2004) Assay variation confounds the diagnosis of hypovitaminosis D: a call for standardization. J Clin Endocrinol Metabol 89, 3152-3157.

174. Carter GD (2011) Accuracy of 25-hydroxyvitamin D assays: confronting the issues. Curr Drug Targets 12, 19-28.

175. Lai JKC, Lucas RM, Banks E, et al. (2012) Variability in vitamin $\mathrm{D}$ assays impairs clinical assessment of vitamin D status. Intern Med J 42, 43-50.

176. Carter GD, Berry J, Durazo-Arvizu R, et al. (2018) Hydroxyvitamin D assays: an historical perspective from DEQAS. J Steroid Biochem Mol Biol 177, 30-35.

177. Binkley N, Krueger D, Gemar D, et al. (2008) Correlation among 25-hydroxy-vitamin D assays. J Clin Endocrinol Metabol 93, 1804-1808.

178. Carter G, Carter R, Jones J, et al. (2004) How accurate are assays for 25-hydroxyvitamin D? Data from the international vitamin D external quality assessment scheme. Clin Chem 50, 2195-2197.

179. Glendenning P, Taranto M, Noble JM, et al. (2006) Current assays overestimate 25-hydroxyvitamin $\mathrm{D}_{3}$ and underestimate 25-hydroxyvitamin $\mathrm{D}_{2}$ compared with HPLC: need for assayspecific decision limits and metabolite-specific assays. Ann Clin Biochem 43, 23-30.

180. Lensmeyer GL, Wiebe DA, Binkley N, et al. (2006) HPLC method for 25-hydroxyvitamin D measurement: comparison with contemporary assays. Clin Chem 52, 1120-1126. 
181. Lips P, Chapuy MC, Dawson-Hughes B, et al. (1999) An international comparison of serum 25-hydroxyvitamin D measurements. Osteoporos Int 9, 394-397.

182. Carter GD (2009) 25-Hydroxyvitamin D assays: the quest for accuracy. Clin Chem 55, 1300.

183. Black LJ, Anderson D, Clarke MW, et al. (2015) Analytical bias in the measurement of serum 25-hydroxyvitamin D concentrations impairs assessment of vitamin D status in clinical and research settings. PLOS ONE 10, e0135478.

184. Sempos CT, Heijboer AC, Bikle DD, et al. (2018) Vitamin D assays and the definition of hypovitaminosis D: results from the first international conference on controversies in vitamin D. Br J Clin Pharmacol 84, 2194-2207.

185. Abu Kassim NS, Shaw PN \& Hewavitharana AK (2018) Simultaneous determination of 12 vitamin D compounds in human serum using online sample preparation and liquid chromatography-tandem mass spectrometry. J Chromatogr A 1533, 57-65.

186. Hewavitharana AK, Abu Kassim NS \& Shaw PN (2018) Standard addition with internal standardisation as an alternative to using stable isotope labelled internal standards to correct for matrix effects - Comparison and validation using liquid chromatography-tandem mass spectrometric assay of vitamin D. J Chromatogr A 1553, 101-107.

187. Swanson CM, Nielson CM, Shrestha S, et al. (2014) Higher $25(\mathrm{OH}) \mathrm{D}_{2}$ is associated with lower $25(\mathrm{OH}) \mathrm{D}_{3}$ and $1,25(\mathrm{OH})$ 2D. J Clin Endocrinol Metab 99, 2736-2744.

188. Tripkovic L, Lambert H, Hart K, et al. (2012) Comparison of vitamin D-2 and vitamin D-3 supplementation in raising serum 25-hydroxyvitamin D status: a systematic review and metaanalysis. Am J Clin Nutr 95, 1357-1364.

189. Romagnoli E, Mascia ML, Cipriani C, et al. (2008) Short and long-term variations in serum calciotropic hormones after a single very large dose of ergocalciferol (vitamin $\mathrm{D}_{2}$ ) or cholecalciferol (vitamin $\mathrm{D}_{3}$ ) in the elderly. J Clin Endocrinol Metab 93, 3015-3020.

190. Nguyen $T$ (2017) Cholecalciferol $\left(D_{3}\right)$ versus ergocalciferol $\left(\mathrm{D}_{2}\right)$ : which vitamin D to use? J Nurse Pract 13, 442-443.

191. Cashman KD, Dowling KG, Škrabáková Z, et al. (2015) Standardizing serum 25-hydroxyvitamin D data from four nordic population samples using the vitamin D Standardization Program protocols: shedding new light on vitamin D status in nordic individuals. Scandinavian J Clin Lab Invest $\mathbf{7 5}$, $549-561$

192. Houghton LA \& Vieth R (2006) Case against ergocalciferol (vitamin $\mathrm{D}_{2}$ ) as a vitamin supplement. Am J Clin Nutr 84, 694-697.

193. Jones KS, Assar S, Harnpanich D, et al. (2014) $25(\mathrm{OH}) \mathrm{D}_{2}$ half-life is shorter than $25(\mathrm{OH}) \mathrm{D}_{3}$ half-life and is influenced by DBP concentration and genotype. J Clin Endocrinol Metab 99, 3373-3381.

194. Yang M, Qin Z, Zhu Y, et al. (2013) Vitamin D-binding protein in cerebrospinal fluid is associated with multiple sclerosis progression. Mol Neurobiol 47, 946-956.

195. Jirikowski GF, Kaunzner UW, Dief Ael E, et al. (2009) Distribution of vitamin D binding protein expressing neurons in the rat hypothalamus. Histochem Cell Biol 131, 365-370.

196. Speeckaert MM, Speeckaert R, van Geel N, et al. (2014) Vitamin D binding protein-chapter one: a multifunctional protein of clinical importance: a multifunctional protein of clinical importance. Adv Clin Chem 63, 1-57.

197. Kamboh MI \& Ferrell RE (1986) Ethnic variation in vitamin D-binding protein (GC): a review of isoelectric focusing studies in human populations. Hum Genet $\mathbf{7 2}$, 281-293.
198. Jassil N, Sharma A, Bikle D, et al. (2017) Vitamin D binding protein and 25-hydroxyvitamin D levels: emerging clinical applications. Endocr Pract 23, 605-613.

199. Yousefzadeh P, Shapses SA \& Wang X (2014) Vitamin D binding protein impact on 25-hydroxyvitamin D levels under different physiologic and pathologic conditions. Int $J$ Endocrinol 2014, 981581.

200. Jorde R, Mathiesen EB, Rogne S, et al. (2015) Vitamin D and cognitive function: the Tromso Study. J Neurol Sci $\mathbf{3 5 5}$, 155-161.

201. Lauridsen AL, Vestergaard P \& Nexo E (2001) Mean serum concentration of vitamin D-binding protein (Gc globulin) is related to the Gc phenotype in women. Clin Chem $\mathbf{4 7}$, 753-756.

202. Arnaud J \& Constans J (1993) Affinity differences for vitamin D metabolites associated with the genetic isoforms of the human serum carrier protein (DBP). Hum Genet 92, 183-188.

203. Chun RF, Peercy BE, Adams JS, et al. (2012) Vitamin D binding protein and monocyte response to 25 -hydroxyvitamin $\mathrm{D}$ and 1,25-dihydroxyvitamin D: analysis by mathematical modeling (Vitamin D Math Modeling). PLOS ONE 7, e30773.

204. Engelman CD, Fingerlin TE, Langefeld CD, et al. (2008) Genetic and environmental determinants of 25-hydroxyvitamin D and 1,25-dihydroxyvitamin D levels in Hispanic and African Americans. J Clin Endocrinol Metab 93, 3381-3388.

205. Hoofnagle AN, Eckfeldt JH \& Lutsey PL (2015) Vitamin D-binding protein concentrations quantified by mass spectrometry. New England J Med 373, 1480-1482.

206. Powe CE, Evans MK, Wenger J, et al. (2013) Vitamin D-binding protein and vitamin D status of black Americans and White Americans. New England J Med 369, 1991-2000.

207. Harris SS (2006) Vitamin D and African Americans. J Nutr 136, 1126-1129.

208. Lutsey PL, Michos ED, Misialek JR, et al. (2015) Race and vitamin $\mathrm{D}$ binding protein gene polymorphisms modify the association of 25-hydroxyvitamin D and incident heart failure: the ARIC (Atherosclerosis Risk in Communities) study. JACC Heart Fail 3, 347-356.

209. Sinotte M, Diorio C, Bérubé S, et al. (2009) Genetic polymorphisms of the vitamin $\mathrm{D}$ binding protein and plasma concentrations of 25-hydroxyvitamin D in premenopausal women. Am J Clin Nutr 89, 634

210. Wang TJ, Zhang F, Richards JB, et al. (2010) Common genetic determinants of vitamin D insufficiency: a genome-wide association study. Lancet 376, 180-188.

211. Levin GP, Robinson-Cohen C, de Boer IH, et al. (2012) Genetic variants and associations of 25-hydroxyvitamin D concentrations with major clinical outcomes. JAMA 308, 1898-1905.

212. Santos BR, Mascarenhas LP, Boguszewski MC, et al. (2013) Variations in the vitamin D-binding protein (DBP) gene are related to lower 25-hydroxyvitamin D levels in healthy girls: a cross-sectional study. Horm Res Paediatr 79, 162-168.

213. Pop LC, Shapses SA, Chang B, et al. (2015) Vitamin D-binding protein in healthy pre- and postmenopausal women: relationship with estradiol concentrations. Endocr Pract 21, 936-942.

214. Carpenter TO, Zhang JH, Parra E, et al. (2013) Vitamin D binding protein is a key determinant of 25-hydroxyvitamin D levels in infants and toddlers. J Bone Miner Res 28, 213-221.

215. Jones KS, Redmond J, Fulford AJ, et al. (2017) Diurnal rhythms of vitamin D binding protein and total and free vitamin D metabolites. J Steroid Biochem Mol Biol 172, 130-135.

216. Karlsson T, Osmancevic A, Jansson N, et al. (2014) Increased vitamin D-binding protein and decreased free $25(\mathrm{OH}) \mathrm{D}$ in obese women of reproductive age. Eur J Nutr 53, 259-267. 
217. Ashraf AP, Huisingh C, Alvarez JA, et al. (2014) Insulin resistance indices are inversely associated with vitamin $\mathrm{D}$ binding protein concentrations. J Clin Endocrinol Metab 99, 178-183.

218. Blanton D, Han Z, Bierschenk L, et al. (2011) Reduced serum vitamin D-binding protein levels are associated with type 1 diabetes. Diabetes 60, 2566-2570.

219. Stokes CS, Volmer DA, Grunhage F, et al. (2013) Vitamin D in chronic liver disease. Liver Int 33, 338-352.

220. Denburg MR, Kalkwarf HJ, de Boer IH, et al. (2013) Vitamin D bioavailability and catabolism in pediatric chronic kidney disease. Pediatr Nephrol 28, 1843-1853.

221. Lerner PP, Sharony L \& Miodownik C (2018) Association between mental disorders, cognitive disturbances and vitamin D serum level: current state. Clin Nutr ESPEN 23, 89-102.

222. Soliman A (2016) Vitamin D deficiency: a major global epidemic that requires effective strategy and guidelines for management. Indian J Endocr Metab 18, 1-3.

223. Harvard Women's Health Watch (2017) Taking too much vitamin D can cloud its benefits and create health risks. https://www.health.harvard.edu/staying-healthy/taking-toomuch-vitamin-d-can-cloud-its-benefits-and-create-health-risks (accessed June 2018).

224. Statistics ABO (2011-2012) Australian Health Survey: biomedical results for nutrients, 2011-12 (no. 4364.0.55.006). https:// www.abs.gov.au/ausstats/abs@.nsf/Lookup/4364.0.55.006 main+features12011-12 (accessed June 2018).

225. Janz T \& Pearson C (2015) Health at a glance: vitamin D blood levels of Canadians. https://www150.statcan.gc.ca/n1/pub/82624-x/2013001/article/11727-eng.htm (accessed June 2018).

226. Manson JE, Bassuk SS, Lee IM, et al. (2012) The VITamin D and OmegA-3 TriaL (VITAL): rationale and design of a large randomized controlled trial of vitamin $\mathrm{D}$ and marine omega-3 fatty acid supplements for the primary prevention of cancer and cardiovascular disease. Contemp Clin Trials 33, 159-171.

227. Scragg R, Waayer D, Stewart AW, et al. (2016) The Vitamin D Assessment (ViDA) Study: design of a randomized controlled trial of vitamin D supplementation for the prevention of cardiovascular disease, acute respiratory infection, falls and non-vertebral fractures. J Steroid Biochem Mol Biol 164, 318-325.

228. Neale RE, Armstrong BK, Baxter C, et al. (2016) The D-health trial: a randomized trial of vitamin $\mathrm{D}$ for prevention of mortality and cancer. Contemp Clin Trials 48, 83-90.

229. Bacon CJ, Gamble GD, Horne AM, et al. (2009) High-dose oral vitamin $\mathrm{D}_{3}$ supplementation in the elderly. Osteoporos Int 20, 1407-1415.

230. Bischoff-Ferrari HA, Dawson-Hughes B, Orav EJ, et al. (2016) Monthly high-dose vitamin D treatment for the prevention of functional decline: a randomized clinical trial. JAMA Intern Med 176, 175-183.

231. Burton JM, Kimball S, Vieth R, et al. (2010) A phase I/II doseescalation trial of vitamin $\mathrm{D}_{3}$ and calcium in multiple sclerosis. Neurology 74, 1852-1859.

232. Feldman F, Moore C, da Silva L, et al. (2014) Effectiveness and safety of a high-dose weekly vitamin D (20,000 IU) protocol in older adults living in residential care. J Am Geriatr Soc $\mathbf{6 2}$, $1546-1550$.

233. Rizzoli R, Boonen S, Brandi ML, et al. (2013) Vitamin D supplementation in elderly or postmenopausal women: a 2013 update of the 2008 recommendations from the European Society for Clinical and Economic Aspects of Osteoporosis and Osteoarthritis (ESCEO). Curr Med Res Opin 29, 305-313.

234. Sarkar S, Chopra S, Rohit MK, et al. (2016) Vitamin D regulates the production of vascular endothelial growth factor: a triggering cause in the pathogenesis of rheumatic heart disease? Med Hypotheses 95, 62-66.

235. Mani N, Khaibullina A, Krum JM, et al. (2005) Astrocyte growth effects of vascular endothelial growth factor (VEGF) application to perinatal neocortical explants: receptor mediation and signal transduction pathways. Exp Neurol 192, 394-406.

236. Rosenstein JM, Krum JM \& Ruhrberg C (2010) VEGF in the nervous system. Organogenesis 6, 107-114.

237. Hayakawa K, Pham L-DD, Som AT, et al. (2011) Vascular endothelial growth factor regulates the migration of oligodendrocyte precursor cells. J Neurosci 31, 10666-10670.

238. Ding X, Gu R, Zhang M, et al. (2018) Microglia enhanced the angiogenesis, migration and proliferation of co-cultured RMECs. BMC Ophthalmol 18, 249.

239. Shize J, Rui X, Yong J, et al. (2014) Vascular endothelial growth factors enhance the permeability of the mouse blood-brain barrier. PLOS ONE 9, e86407.

240. Westerfeld CB \& Miller JW (2010) Chapter 66 Neovascularization in diabetic retinopathy. In Ocular Disease, pp. 514-518 [LA Levin and DM Albert, editors]. Edinburgh: W.B. Saunders.

241. Dulak J, Jozkowicz A, Dembinska-Kiec A, et al. (2000) Nitric oxide induces the synthesis of vascular endothelial growth factor by rat vascular smooth muscle cells. Arterioscler Thromb Vasc Biol 20, 659-666.

242. Al-Daghri NM, Bukhari I, Yakout SM, et al. (2018) Associations of serum nitric oxide with vitamin D and other metabolic factors in apparently healthy adolescents. BioMed Res Int $\mathbf{2 0 1 8}$, 1489132.

243. Dalan R, Liew H, Tan WKA, et al. (2014) Vitamin D and the endothelium: basic, translational and clinical research updates. IJC Metab Endocrine 4, 4-17. 